\title{
Tackling Antibiotic Resistance with Compounds of Natural Origin: A Comprehensive Review
}

\author{
Francisco Javier Álvarez-Martínez ${ }^{1}$ (1) Enrique Barrajón-Catalán ${ }^{1, *}$ (i) and Vicente Micol ${ }^{1,2}$ (D) \\ 1 Institute of Research, Development and Innovation in Health Biotechnology of Elche (IDiBE), \\ Universitas Miguel Hernández (UMH), 03202 Elche, Spain; f.alvarez@umh.es (F.J.Á.-M.); \\ vmicol@umh.es (V.M.) \\ 2 CIBER, Fisiopatología de la Obesidad y la Nutrición, CIBERobn, \\ Instituto de Salud Carlos III (CB12/03/30038), 28220 Madrid, Spain \\ * Correspondence: e.barrajon@umh.es; Tel.: +34-965222586
}

Received: 18 September 2020; Accepted: 9 October 2020; Published: 11 October 2020

\begin{abstract}
Drug-resistant bacteria pose a serious threat to human health worldwide. Current antibiotics are losing efficacy and new antimicrobial agents are urgently needed. Living organisms are an invaluable source of antimicrobial compounds. The antimicrobial activity of the most representative natural products of animal, bacterial, fungal and plant origin are reviewed in this paper. Their activity against drug-resistant bacteria, their mechanisms of action, the possible development of resistance against them, their role in current medicine and their future perspectives are discussed. Electronic databases such as PubMed, Scopus and ScienceDirect were used to search scientific contributions until September 2020, using relevant keywords. Natural compounds of heterogeneous origins have been shown to possess antimicrobial capabilities, including against antibiotic-resistant bacteria. The most commonly found mechanisms of antimicrobial action are related to protein biosynthesis and alteration of cell walls and membranes. Various natural compounds, especially phytochemicals, have shown synergistic capacity with antibiotics. There is little literature on the development of specific resistance mechanisms against natural antimicrobial compounds. New technologies such as -omics, network pharmacology and informatics have the potential to identify and characterize new natural antimicrobial compounds in the future. This knowledge may be useful for the development of future therapeutic strategies.
\end{abstract}

Keywords: natural antimicrobial; antimicrobial resistance; polyphenols; future medicine; natural origin; antibacterial compound; phytochemicals

\section{Introduction}

Antimicrobial resistance (AMR) and the inexorable advance of superbacteria poses a great threat to human health worldwide. If this problem is not tackled, the antibiotics we have used with great success so far could become substances unable to help us against infections caused by bacteria, going back to a worrying pre-antibiotic era. According to data from the United Kingdom government [1], 10 million deaths could happen annually due to antibiotic resistance by 2050, becoming one of the leading causes of death in the world (Figure 1).

This problem is known to scientists and institutions around the world, which are organizing to establish protocols to address the problem of antibiotic-resistant microbes. Proof of this was the 2012 Chennai Declaration of India, in which international experts and representatives of medical entities met to draw up action plans in the face of the inexorable advance of the superbugs [2]. Similar initiatives have been promoted from private and public institutions worldwide. 
Leading causes of death in the world, 2016 (in millions)

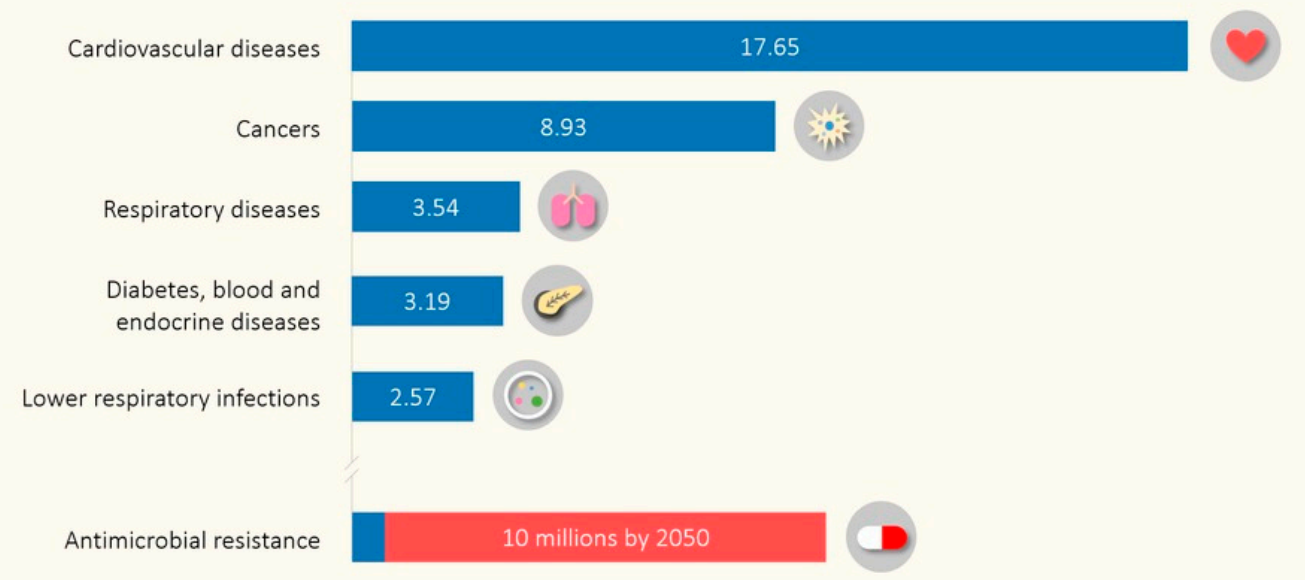

Figure 1. Leading causes of death in the world in 2016 (blue bars) and prognosis for antimicrobial resistance (AMR) related deaths in 2050 (red bar).

Bacteria use their genetic plasticity to resist attack by antibiotics through mutations, acquisition of genetic material, and alteration of the expression of their genome [3]. In this way, bacteria that survive the attack of an antibiotic become the precursors of the next bacterial generations, further aggravating the problem of resistance. Once antibiotic resistance genes are acquired, they can be passed from one bacterium to another through division processes or by horizontal gene transfer [4]. Horizontal gene transfer processes can occur by transformation, transduction or conjugation with other bacteria. These mechanisms can transfer antibiotic resistance to bacteria that have not been subjected to antibiotic selection pressure, creating reservoirs of resistant bacteria in the environment [5]. In addition, the epistasis of the receptor bacteria plays a fundamental role in the process of acquisition of resistance genes, determining whether these bacteria are capable of maintaining, accumulating and propagating the genetic material [6].

Antibiotic resistance is an example of the enormous capacity for natural evolution and adaptation of bacteria to different environments [7,8]. Although this process seems inevitable, humans have accelerated it through various anthropogenic activities $[9,10]$. The causes behind the increase in the number of antimicrobial-resistant bacteria in recent years include the misuse of antibiotics in humans and animals, inadequate control of infections in hospitals and clinics or poor hygiene and sanitation [9-11]. In addition to the causes mentioned, the problem worsens as there is a drought in the discovery of new antibiotics. The increase in resistance rates in bacteria leads to a decrease in the effectiveness of existing antibiotics, making research in this field unattractive to companies that decide to invest in other types of fields with greater chances of success and benefits $[12,13]$. This concerning trend can be observed in Figure 2.

In view of this scenario, research on alternative or complementary therapies to traditional antibiotics has emerged strongly. Antimicrobial products of natural origin have been positioned as compounds of great scientific interest due to their enormous chemical variety and intrinsic properties that have promoted their study as a possible therapeutic tool in recent years. 


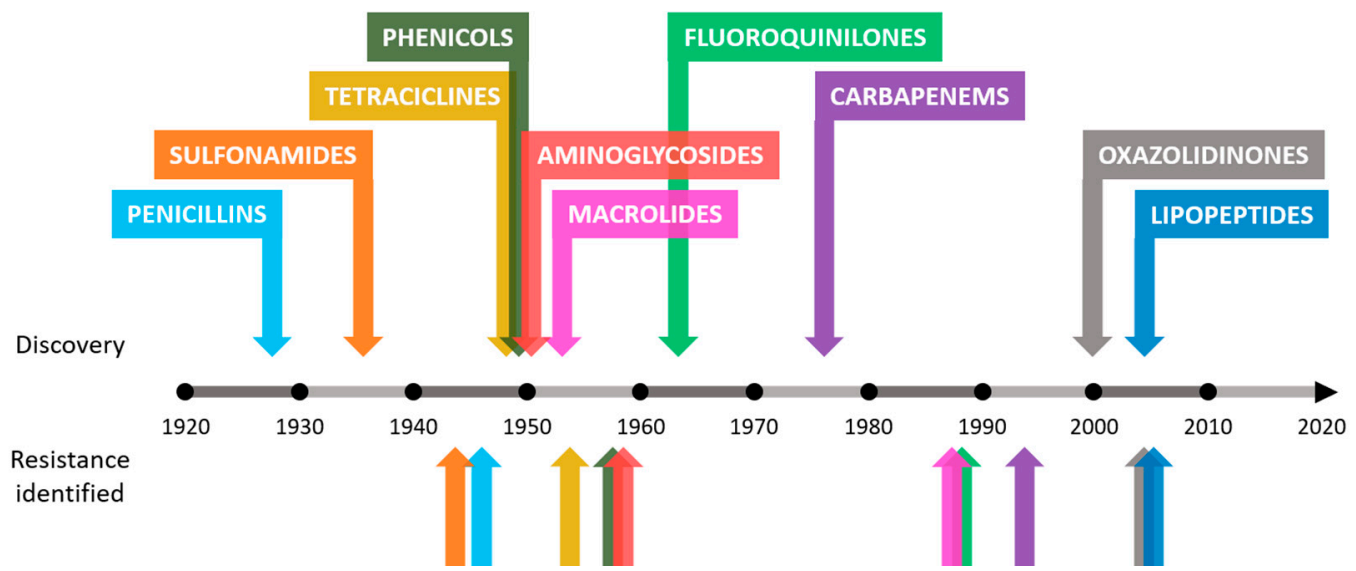

Figure 2. Approximate dates of discovery of new classes of antibiotics and identification of bacterial resistance.

\section{Methodology}

Electronic databases such as PubMed, Scopus and ScienceDirect were used to search scientific contributions until September 2020, using relevant keywords. Search terms included "natural antimicrobial", "antimicrobial resistance", "polyphenols", "future medicine", "natural origin", "antibacterial compound", "phytochemical" and their combinations. Literature focusing on the antimicrobial activity of natural origin compounds against bacteria focusing on antibiotic-resistant strains were identified and summarized.

The term "antimicrobial activity" is used throughout this work to refer to the process of killing or inhibiting the growth of microbes. Usually, this activity is expressed as MIC (minimum inhibitory concentration) values for a given agent. The methods to test microbial susceptibility compiled in this work are in accordance with the guidelines of the European Committee on Antimicrobial Susceptibility Testing (EUCAST) and The Clinical and Laboratory Standards Institute (CLSI). Following the EUCAST guidelines for the reproducibility and reliability of antimicrobial assays, broth dilution or microdilution methods should be used to test microbial susceptibility [14].

\section{Results}

\subsection{Use of Natural Products as Antimicrobials}

Natural products (NPs) make up a heterogeneous group of chemical entities that possess diverse biological activities with various uses in fields such as human and veterinary medicine, agriculture and industry. Molecules from the secondary metabolism of animals, vegetables, bacteria and fungi are classified as NPs, which are not crucial for the producer's survival under laboratory conditions, but which give him a clear advantage over his competitors in his native habitat [15]. Since the discovery of penicillin, more than 23,000 new NPs have been characterized, many of which have proven to be valuable tools in the field of pharmacology, herbicides, insecticides and more [16].

One of the main sources of antimicrobial NPs is plants. Plant organisms make up most of the biosphere on planet Earth, whose biomass accounts for a percentage greater than $80 \%$ of the total biomass [17]. Since their appearance, plants have survived, evolved and adapted to all types of ecosystems and adverse conditions. This adaptive process has led them to develop complex and effective defense systems against external aggressions: predators, abiotic stress and, of course, infections. Being sessile organisms that cannot escape their threats, plants have developed a splendid chemical arsenal in the form of secondary metabolites capable of coping with the most dangerous pathogens [18]. Humanity has made use of the medicinal properties of plants for thousands of years. There is evidence that in the year 5000 BC. the Sumerians already used thyme for its beneficial health properties [19]. The Egyptian Ebers Papyrus dating from around 1500 BC already attributed medicinal properties to 
plants and spices such as aloe vera, castor bean, garlic, hemp, anise or mustard [20,21]. Other texts such as the Atharva Veda, the Rig Veda and the Sushruta Samhita belonging to Indian Ayurveda, also spoke of the pharmacological properties of plant substances such as turmeric or cannabis [22,23]. Current technology allows us to study the bases of this ancestral knowledge and find therapeutic applications adapted to our time, making plants a source of invaluable therapeutic potential.

Bacteria are another of the main sources of antimicrobial NPs with radical importance during the 20th century. Most of the antibiotics used today in the clinic were discovered thanks to the Waksman platform in the 1940s. Waksman and his students dedicated themselves to growing soil microorganisms to detect and isolate antimicrobial substances. Through this method, they discovered very important antibiotics such as neomycin or streptomycin, for which Waksman received the Nobel Prize in 1952 for Physiology or Medicine [24]. Despite these successes, it should be noted that most existing bacteria are not cultivable in the laboratory using traditional methods. We could find an immense amount of opportunities for the isolation of new antibiotic compounds using a method like Waksman's combined with new technologies not present decades ago. From this idea, the Small World Initiative was born in 2012, a project in which students from all over the world collect soil samples and look for antibiotic-producing microorganisms in them [25].

Many of the NPs with antibiotic activity have been isolated from bacteria, especially from the genus actinomycetes. In the so-called "Golden Age" of the discovery of new antibiotics, which began in the 40s of the twentieth century, natural products were the star. The isolation of streptomycin from Streptomyces griseus in 1944 caused a worldwide surge in which numerous research groups struggled to identify new NPs, especially from samples of soil bacteria. The media were very limited, both in technology and in access to soil samples from remote places. However, another great milestone occurred in 1952, when a sample of soil sent from Borneo allowed Streptomyces orientalis to grow, from which vancomycin was extracted. Six years later, vancomycin was used in patients with great success. Unfortunately, this prolific period of discovery of valuable compounds ended the appearance and spread of bacteria resistant to these NPs, such as methicillin-resistant Staphylococcus aureus (MRSA) or glycopeptide-resistant enterococci (GREs), since the compounds that worked in the past stopped working with the desired efficiency [26], as observed in Figure 2.

In the 1990s, the pharmaceutical industry concentrated its efforts on other more sophisticated methods of identifying antimicrobial compounds, such as high-throughput screening of synthetic chemical libraries against specific therapeutic targets, many of them discovered from the Human Genome Project. Currently, there is a renewed interest in the discovery of new NPs of different sources since it has a much more advanced technology than that available during the "Golden Age". Advances in genomics, bioinformatics and mass spectrometry, among others, have elucidated that many of the sources of classical NPs were surprisingly under-exploited and have an enormous and unknown potential for the discovery of new NPs to be used for the discovery of present and tomorrow's antibiotics [15].

Given the existing problems in the field of antibiotics, in recent years alternative and complementary therapies have emerged that make use of different strategies to deal with new generations of resistant bacteria. The growing interest in this area is reflected in the ascending number of publications related to natural antimicrobials available in the PubMed search engine over the past recent years (Figure 3).

As abovementioned, the molecules with antimicrobial function present in nature have been molded by thousands of years of evolution to maintain their efficacy and selectivity, since they are a key piece for the development of the life of any organism exposed to bacteria. Thanks to these processes of continuous physicochemical adaptation driven by selective pressure, it has been demonstrated that antimicrobial compounds of natural origin generally have a greater capacity for cell penetration, being able to use active bacterial transporters and, in addition, passively pass through the cell membrane [27]. These and other properties that will be discussed below, make NPs a tool of great potential value for the development of novel and effective antibiotic therapies against AMR bacteria. 


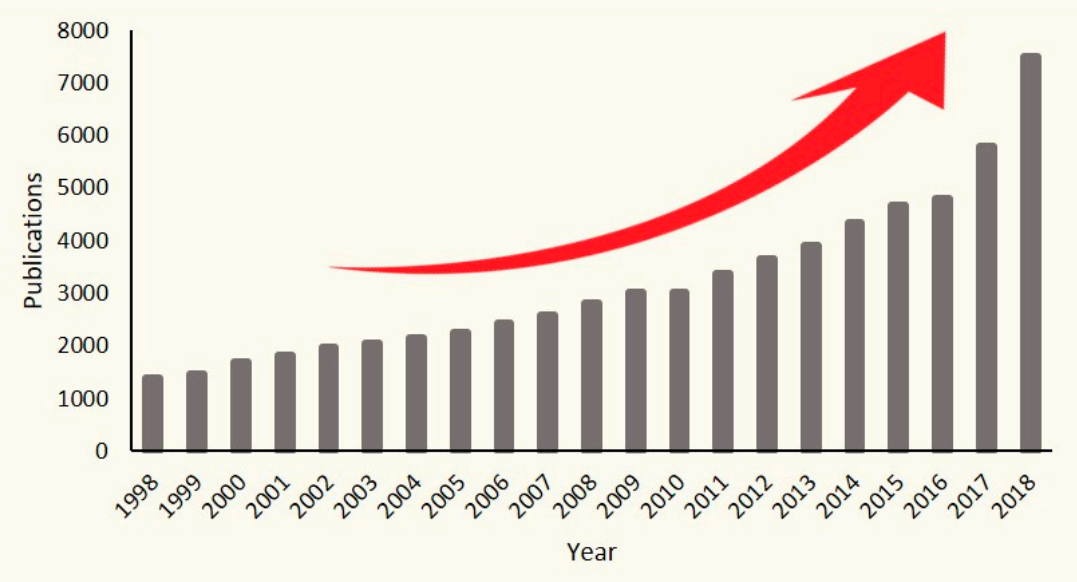

Figure 3. The number of research articles available in PubMed by searching "Natural Antimicrobial" from 1998 to 2018. The red arrow represents a growing trend.

\subsection{Main Classes of Natural Antimicrobial Products}

NPs are extremely diverse in terms of their chemical structures, properties and mechanisms of action. These agents can be classified according to their original source: animal, bacterial, fungal or vegetal.

\subsubsection{Animal Origin}

Animals have colonized virtually the entire planet Earth. For thousands of years, they have lived closely with different kinds of bacteria and have faced not a few pathogenic microorganisms. Evolution has shaped animal defense systems to deal with these microscopic threats. In recent years, attention has been focused on identifying which molecules confer resistance and allow certain animals to live in hostile environments with high pollution and pathogenic load, as is the case with certain insects such as cockroaches.

Currently, animals, and especially insects, are one of the main sources of antimicrobial proteins or peptides (AMPs). Since the discovery of AMPs in 1974, more than 150 new AMPs have been isolated or identified, the majority being cationic peptides between 20 and 50 residues in length. These molecules mainly have antimicrobial capacity mediated by disruption of the bacterial plasma membrane, most probably by forming pores or ion channels [28]. Some AMPs also have shown antifungal, antiparasitic or antiviral properties [29]. These AMPs can be divided into four subfamilies with different structures and sequences: the $\alpha$-helical peptides, such as cecropin, which has a broad spectrum of antimicrobial activity against bacteria of both Gram-positive and Gram-negative bacteria; cysteine-rich peptides, such as insect defensins, which are mainly active against Gram-positive bacteria; proline-rich peptides, such as lebocins, which are active against both Gram-positive and Gram-negative bacteria and some fungi; and finally glycine-rich peptides or proteins, such as attacin, which are effective against Gram-negative bacteria and especially against Escherichia coli. These AMPs present a promising basis for the development of medical therapies, however, additional work must be developed to make them more powerful and stable [30]. Moreover, the intrinsic antimicrobial capacity of AMPs can be enhanced by a fusion of peptides to create more potent hybrid ones, such as in the case of attacin from Spodoptera exigua and a coleoptericin-like protein from Protaetia brevitarsis seulensis, which, when fused, exhibited a greater antimicrobial capacity than its two original peptides [31].

The study of antimicrobial molecules existent in cockroaches (Periplaneta americana) has revealed that extracts derived from its brain have a great antimicrobial capacity against MRSA and neuropathogenic E. coli K1. Although not all the components of the extract could be accurately identified, a great variety of molecules with known biological activity were found, such as isoquinolines, flavanones, sulfonamides and imidazone among others. A hypothesis about the production of this antimicrobial cocktail in the cockroach brain suggests that there could be a constitutive expression of 
these antimicrobials to protect the animal's neural system, since it is the central axis of its survival and a key piece to protect when it is lived in an environment of high pollution and exposure to pathogens and even superbugs [32]. Another example of insect producing antimicrobial molecules against resistant bacteria is Lucilia cuprina blowfly maggots. The extract obtained from excretions and secretions from maggots showed mild bacterial growth inhibition. However, using subinhibitory concentrations of this extract in combination with the antibiotic ciprofloxacin enhanced its activity, further delaying the appearance of bacteria resistant to it. The properties of this extract, including the presence of defensins and phenylacetaldehyde, make maggot debridement therapy a promising tool in the treatment of MRSA-infected wounds acquired in hospital [33].

One of the most popular insect-related products worldwide is honey. In addition to its nutritional properties and culinary values, it has antimicrobial capacity against Gram-negative bacteria, such as E. coli or Pseudomonas aeruginosa, and against Gram-positive bacteria, such as Bacillus subtilis or S. aureus, including MRSA. The key factors of honey's antimicrobial activity appear to be the presence of $\mathrm{H}_{2} \mathrm{O}_{2}$, bee defensin-1 and methylglyoxal. The diverse molecular composition of the different honey types that depends on the producing species and the raw material used, exerts also different antimicrobial activities and mechanisms [34]. Another substance produced by bees is propolis, a resinous substance produced by honeybees from plant matter, such as buds or sap. This substance has been used since ancient times, up to 3000 years BC in Egypt thanks to its various biological properties. The main components responsible for its activity are flavonoids, terpene derivatives and phenolic acids, although its composition is variable depending on the geographical area where it occurs. Ethanol extract of propolis produced by Apis mellifera in Brazil has demonstrated significant antibacterial capacity against S. aureus, E. coli and Enterococcus sp. [35]. Canadian propolis has also been shown to possess antibacterial capacity against E. coli and $S$. aureus, being more effective against the latter [36]. Another product with antimicrobial properties derived from honeybees is royal jelly. It is produced from the mandibular salivary and hypopharyngeal glands of bees aged between 5 and 14 days. Its composition is based on a complex mixture of carbohydrates, proteins, lipids, vitamins and minerals that varies with regional conditions, season, bee's genetics and postharvest storage conditions. Royal jelly shows antimicrobial activity against both Gram-positive and Gram-negative bacteria, including MDR bacteria such as MRSA. The compounds isolated from royal jelly with activity against Gram-positive bacteria are the peptide royalisin [37], the peptide family of jelleines and 10-hydroxy-2-decenoic acid (10-HDA), also known as queen bee acid [38]. Melittin, a major component from the venom of A. mellifera, has also shown interesting antimicrobial activity, including in in vivo experiments with mice infected with MRSA [39].

Other animals that can live in contaminated environments and exposed to infections are reptiles, such as snakes that are able to ingest rodents infected with germs and not develop a disease. Results suggest that animals exposed to huge amounts of pathogens can be a valuable source of antimicrobial molecules. However, to further study and identification of the key molecules responsible for the activity, it is necessary to know if they would be candidates for drugs with real applicability in therapies [40]. There are studies in Black cobra (Naja naja karachiensis) that show that plasma lysates and certain organs have a potent antimicrobial capacity against E. coli K1, MRSA, P. aeruginosa, Streptococcus pneumoniae, Acanthamoeba castellanii, and Fusarium solani. Against E. coli K1, solutions containing 25\% and 50\% of plasma from the blood of the Black cobra showed a bactericidal activity of $85 \%$ and $93 \%$ respectively with respect to the effect of the antibiotic gentamicin. Against MRSA, concentrations of $25 \%$ and $50 \%$ of plasma showed activity of $90 \%$ and $93 \%$, respectively. Lung and gallbladder lysates also showed high antimicrobial capacity against MRSA. Antimicrobial molecules can also be extracted from the venom produced by certain species of snakes, such as cathelicidines or toxins. A cathelicidin-like antimicrobial peptide (cathelicidin-BF) isolated from the venom of Bungarus fasciatus has shown high antimicrobial activity, including drug-resistant bacteria [41]. Crotalus adamanteus toxin-II (CaTx-II) exerted a strong antimicrobial effect against S. aureus, Burkholderia pseudomallei and Enterobacter aerogenes by causing pores and damaging their membranes. Interestingly, this compound showed no cytotoxicity against lung (MRC-5), skin fibroblast (HEPK) cells or treated mice [42]. 
Molecules with great antimicrobial capacity have also been found in crustaceans, coming from their immune system. The anti-lipopolysacchride factor of red claw crayfish Cherax quadricarinatus has shown low minimum bactericidal concentrations (MBC) against Gram-negative Shigella flexneri $(\mathrm{MBC}<6 \mu \mathrm{M})$ and Gram-positive S. aureus $(\mathrm{MBC}<12 \mu \mathrm{M})$, meaning a high antimicrobial capacity. Studies showed that the mechanism of action of this compound does not appear to be related to the bacterial plasma membrane alteration, requiring more studies to find its specific mechanism [43].

The venom of Vaejovis mexicanus, a mexican scorpion, has an AMP called vejovine, which presents a high antimicrobial capacity against MDR Gram-negative bacteria with MIC values between $4.4 \mu \mathrm{M}$ and $50 \mu \mathrm{M}$ [44].

\subsubsection{Bacterial Origin}

Bacteria are the most prolific source of NPs with antimicrobial activity found so far, especially those of the actinomycetes class. Their great diversity, competitiveness and colonization capacity have led them to the development of secondary metabolites capable of giving them great advantages over other bacterial species. As described in previous sections, the detection and isolation of these bacterial antimicrobial NPs propelled medical science vertiginously in the middle of the last century. Some of the most relevant are described below.

Some of the most important antimicrobial molecules produced by bacteria of the actinomyces class are: vancomycin, baulamycin, fasamycin A and orthoformimycin. Vancomycin is a naturally occurring tricyclic glycopeptide extracted from Streptococcus orientalis that has reaped great success as an antibiotic against Gram-positive bacteria, especially against threats that are resistant to other treatments such as MRSA and penicillin-resistant pneumococci among others [45]. Vancomycin forms hydrogen bonds with the terminal dipeptide of the nascent peptidoglycan chain during biosynthesis of the bacterial cell wall. This union prevents the action of penicillin-binding proteins (PBPs), interrupting further wall formation and finally activating autolysin-triggered cell rupture and cell death [46]. Another important bacterial NP is produced by actinomyces is baulamycin, which is an isolated molecule of the marine bacterium Streptomyces tempisquensis that can inhibit the biosynthesis of iron-chelating siderophores in S. aureus (targeting staphylopherrin B) and Bacillus anthracis (targeting petrobactin), helping to treat MRSA and anthrax infections, respectively. In addition, it was also able to inhibit the growth of Gram-negative bacteria such as S. flexneri and E. coli, turning baulamycin and its derivatives into potential broad-spectrum antibiotics [47]. Fasamycin A is a polyketide isolated from Streptomyces albus that shows specific antimicrobial activity against Gram-positive bacteria such as vancomycin-resistant Enterococci (VRE) and MRSA with MIC values of 0.8 and $3.1 \mu \mathrm{g} / \mathrm{mL}$, respectively. This molecule targets FabF in the initial condensation step of the elongation cycle from the lipidic biosynthetic bacterial metabolism [48]. Orthoformimycin is a molecule produced by S. griseus which can inhibit bacterial translation by more than $80 \%$ in the case of E. coli. Although the mechanism of action is not clear now, one hypothesis is the decoupling of mRNA and aminoacyl-tRNA in the bacterial ribosome [49].

The actinobacteria class is also prolific in the production of antimicrobial molecules. One example is kibdelomycin, which is a potent inhibitor of DNA synthesis that was isolated from Kibdelosporangium sp., MA7385. Its complex structure and its infrequent function as an inhibitor of bacterial DNA gyrase and IV topoisomerase make kibdelomycin the first bacterial type II topoisomerase inhibitor discovered from natural sources in more than 60 years [50]. This molecule has a broad-spectrum antimicrobial activity against aerobic bacteria, including antibiotic-resistant bacteria such as MRSA, with a MIC value of $0.25 \mu \mathrm{g} / \mathrm{mL}$. In addition, this molecule has a very low resistance development rate due to its structure and way of binding with its target, at levels of other successful antibiotics such as ciprofloxacin [51]. Another example is pyridomycin, a molecule isolated from Dactylosporangium fulvum which has a great antimicrobial capacity against mycobacteria, a bacterium that causes tuberculosis. This disease is becoming relevant due to the appearance of bacteria resistant to the main antibiotics used for its treatment such as the InhA inhibitor isoniazid. Pyridomycin acts on the cell wall of Mycobacterium tuberculosis by inhibiting the production of mycolic acid by targeting NADH-dependent enoyl- (Acyl-Carrier-Protein) 
reductase InhA even in strains resistant to isoniazid. Pyridomycin showed minimum bactericidal concentration (MBC) values between 0.62 and $1.25 \mu \mathrm{g} / \mathrm{mL}$ against $M$. tuberculosis [52].

In addition to the two classes mentioned above, there are other classes of bacteria such as deltaproteobacteria, cyanophyceae or betaproteobacteria from which antimicrobial molecules have also been isolated. Myxovirecin is a macrocyclic secondary metabolite isolated from myxobacteria (deltaproteobacteria class) that possesses broad-spectrum antibacterial capacity. It seems to inhibit the production of type II signal peptidase by blocking Lpp lipoprotein processing. Myxovirecin showed very potent activity against $E$. coli DW37 with a MIC of $0.063 \mu \mathrm{g} / \mathrm{mL}$ [53]. Spirohexenolide A is a natural spirotetronate originally isolated from Spirulina platensis of the cyanophyceae class that shows antimicrobial activity against methicillin-resistant $S$. aureus by disrupting the cytoplasmic membrane, collapsing the proton motive force [54]. Teixobactin is a naturally occurring molecule produced by Eleftheria terrae of the betaproteobacteria class that possesses antibacterial capacity against antibiotic-resistant pathogens in infection animal models. It acts by binding to the precursors of the bacterial wall teicoic acid, causing the digestion of the cell wall by autolysins [55].

Lypoglycopeptides isolated from different bacteria show antimicrobial activity by inhibiting signal peptidase type IB (SpsB), which is a membrane-localized serine protease that cleaves the amino-terminal signal peptide from most secreted proteins. One example is actinocarbasin, a molecule isolated from Actinoplanes ferrugineus strain MA7383. Moreover, this molecule enhances the activity of $\beta$-lactam antibiotics against MRSA, sensitizing it to those drugs. Arylomycin is another lipoglycopeptide with bacterial type I signal peptidase inhibitory capacity which showed antibacterial activity witch MIC values in the range of 4-64 $\mu \mathrm{M}$ against Gram-positive and 8-64 $\mu \mathrm{M}$ against Gram-negative bacteria. Krisynomycin is also a lypoglycopeptide, isolated from Streptomyces fradiae strain MA7310, with the capacity of inhibition of SpsB [56].

In addition to the natural bacteria molecules with direct antimicrobial activity, there are also others capable of attacking the virulence factors caused by bacterial infections. Skyllamycins B and C are cyclic depsipeptides isolated from marine bacterial fractions with P. aeruginosa biofilm inhibition and dispersal activity. The ability to prevent the formation of biofilms or to disperse those already formed is of great importance since these biofilms are one of the major causes of drug resistance in nosocomial infections. These molecules do not possess a bactericidal capacity per se, but they are effective in combination with antibiotics that are not able to act in the presence of biofilms, causing them to recover their activity as in the case of azithromycin [57].

\subsubsection{Fungal Origin}

Fungi are eukaryotic-type living things, such as mushrooms, yeasts, and molds. Currently, the existence of some 120,000 species of fungi has been accepted, however, it is estimated that the number of different species of fungi present on earth could be between 2.2 and 3.8 million [58]. This relatively unexplored kingdom is a source of antimicrobial NPs and has great potential to be studied in the future as new species are discovered and identified.

Aspergillomarasmine A is a polyaminoacid naturally produced by Aspergillus versicolor capable of inhibiting antibiotic resistance enzymes in Gram-negative pathogenic bacteria, such as Enterobacteriaceae, Acinetobacter spp., Pseudomonas spp. and Klebsiella pneumoniae. This compound has been used successfully to reverse resistance in mice infected with meropenem-resistant $K$. pneumoniae thanks to the NDM-I protein, making the bacterium sensitive to the antibiotic and ending the infection [59].

Mirandamycin is a quinol of fungal origin capable of inhibiting the growth of both Gram-negative and Gram-positive bacteria, being more effective against the latter group, including antibiotic-resistant strains such as MRSA or carbapenemase-producing K. pneumoniae. Its mechanism of action consists in the inhibition of the bacterial metabolism of sugars, interfering with their fermentation and transport [60].

There is evidence of the antibacterial capacity of various fungal species against Gram-positive bacteria. Extracts of Ganoderma lucidum, Ganoderma applanatum, Meripilus giganteus, Laetiporus sulphureus, 
Flammulina velutipes, Coriolus versicolor, Pleurotus ostreatus and Panus tigrinus demonstrated antimicrobial activity in Kirby-Bauer assays against Gram-positive bacteria, such as S. auerus and B. luteus [61].

In recent times, molecules produced by various species of marine fungi have been studied, especially those that cohabit with sponges or corals. Fungal compounds with activity against antibiotic resistant bacteria have been isolated, such as lindgomycin and ascosetin, with MIC values of $5.1 \mu \mathrm{M}$ and 3.2 $\mu \mathrm{M}$ against MRSA, respectively. These molecules were isolated from the mycelium and the Lindgomycetae spp culture broth from sponges found in the Baltic and Antarctic Sea [62]. Another marine fungus capable of producing antimicrobial molecules is Pestalotiopsis sp., isolated from the coral Sarcophyton sp. This fungus produces $( \pm)$-pestalachloride D, a chlorinated benzophenone derivative, which has shown antibacterial capacity against E. coli, Vibrio anguillarum and Vibrio parahaemolyticus with MIC values of 5, 10 and $20 \mu \mathrm{M}$, respectively [63]. Trichoderma sp. is a sponge-derived fungus from which different aminolipopeptide classes, called trichoderins, have been isolated. These molecules have a potent antimycobacterial capacity showing MIC values between 0.02 and $2.0 \mu \mathrm{g} / \mathrm{mL}$ against Mycobacterium smegmatis, Mycobacterium bovis BCG, and M. tuberculosis H37Rv in different aerobic and hypoxic conditions [64].

\subsubsection{Plant Origin}

Plants are a great source of biomolecules with various interesting properties for humans thanks to their enormous diversity and proven safety for human health [65]. Being sessile organisms, evolution has shaped its metabolism to produce certain molecules to cope with external aggressions and infections, since they cannot flee or defend themselves [66]. The Dictionary of Natural Products lists approximately 200,000 secondary plant metabolites, of which 170,000 have unique chemical structures [67]. Some of the families of molecules with antimicrobial capacity produced by plants are alkaloids, terpenoids, and polyphenols [68].

Plants that have been used in traditional medicine in various countries of the world for thousands of years. They are currently being studied at the molecular and functional level, rediscovering their properties and explaining their mechanisms of action.

Alkaloids have been shown to possess antimicrobial capacity against various bacterial species. Although studies of the antimicrobial capacity of pure alkaloids are limited, there are several studies on the antimicrobial activity of plant extracts that contain alkaloids as their main components. Different extracts rich in alkaloids obtained from Papaver rhoeas have shown activity against S. aureus, Staphylococcus epidermidis and K. pneumoniae, the main active component being roemerine [69]. Raw alkaloid-rich extracts of Annona squamosa seeds and Annona muricata root have also shown moderate antimicrobial capacity against E. coli and S. aureus [70].

Terpenoids, along with other families of compounds, are part of plant essential oils, many of which possess antimicrobial activity. Various in vitro studies affirm that terpenoids do not possess significant antimicrobial activity per se [71]. However, they can contribute to the antimicrobial activity of complete essential oils thanks to their hydrophobic nature and a low molecular weight that allow them to disrupt the cell wall and facilitate the action of the rest of the active components [72].

Polyphenols are molecules present in plants with a function of defense against stress and have one or more phenolic groups in their chemical structure as a common feature. There is abundant literature on the antimicrobial capacity of polyphenols and extracts of plants rich in them that have bactericidal and bacteriostatic capacity against many pathogens, both Gram-positive and Gram-negative. The potential use of polyphenols as antimicrobials is widely studied to be applied in different areas such as agriculture [73], food preservation [74] and medicine [75].

There are several subfamilies within the group of polyphenols according to their differentiated chemical structures: flavonoids, hydrolyzable tannins, lignans, phenolic acids and stilbenes. In turn, the flavonoid group can be subdivided into other subfamilies: anthocyanidins, flavanones, flavones, flavonols and isoflavones [76]. Examples of flavonoids with antimicrobial activity are quercetin [77], kaempferol [78], morin [79], myricetin [80] epigallocatechin gallate [81] or galangin [82] among many others $[76,83]$. Other known polyphenols with good antimicrobial activity are punicalagin, which 
exerts both antibacterial and antibiofilm effect against $S$. aureus $[80,84]$, and resveratrol, which has antimicrobial activity against a wide range of bacteria [75].

The growing relevance of the study of polyphenols in the clinical setting is due to their antimicrobial synergy between polyphenols and antibiotics for clinical use. Polyphenols in subinhibitory concentrations enhance the action of an antibiotic against a bacterium that was originally resistant to its effect. For example, kaempferol and quercetin, two flavonols with antimicrobial activity on their own, have also shown to increase the efficacy of the rifampicin antibiotic against rifampicin-resistant MRSA strains by $57.8 \%$ and $75.8 \%$, respectively. The study authors blame this increase in the activity to which these polyphenols are able to inhibit the catalytic activity of topoisomerases, inhibiting DNA synthesis, with a mechanism similar to that of the ciprofloxacin antibiotic, with which they have also shown to have a synergistic activity [85]. Epicatechin gallate (ECg), a flavanol, is capable of sensitizing strains of MRSA against $\beta$-lactam antibiotics such as penicillin or oxacillin. This polyphenol can bind to the MRSA cytoplasmic membrane and cause large changes in its structure and reducing its fluidity, decoupling the functioning mechanism of the enzyme PBP2a, which is the protein responsible for resistance to $\beta$-lactam antibiotics. In addition, ECg can reduce biofilm formation and protein secretion associated with virulence factors [86]. (-)-Epigallocatechin gallate (EGCg) is another flavanol with a great capacity to enhance the effect of antibiotics that acts mainly on the cell wall directly or indirectly and on some virulence factors, such as the production of penicillinases [87].

Another example of synergy between polyphenols and antibiotics is the case of the combination of catechin and epicatechin gallate extracted from Fructus crataegi and ampicillin, ampicillin/sulbactam, cefazolin, cefepime, and imipenem/cilastatin antibiotics, which are usually ineffective against MRSA. These combinations were effective against MRSA in both in vitro and in vivo assays using mice with an established infection model. The authors stressed that the possible mechanism of action of the combination of these two polyphenols to enhance the effect of antibiotics was the accumulation of antibiotics inside the cell thanks to the inhibition of the efflux pump gene [88].

In addition to synergy with antibiotics, there are also studies that point to the synergy between the polyphenols themselves, such as that between EGCg and quercetin against MRSA, attributed to a co-permeabilization process that would facilitate the activity of the compounds inside of the cell [89]. Synergic activity has also been found between the polyphenols quercetin-3-glucoside, punicalagin, ellagic acid and myricetin in different proportions and combinations against $S$. aureus CECT 59 [80].

Apart from the antimicrobial use of concrete molecules of plant origin, the use of complex extracts made from different parts of plants is common and effective. Plant extracts have a great diversity in their composition, since even from the same plant multiple completely different extracts can be obtained varying the extraction conditions. Time, temperature, solvents, pressure and other parameters such as the use of ultrasound or microwave have a huge impact on the final extract composition [90]. There is numerous evidence of the antimicrobial activity of plant extracts $[76,91]$ and the synergistic effect that exists between different phytochemicals [80] when acting against different bacteria. An example of a plant extract with potent activity against AMR bacteria are extracts from Lantana camara leaves against clinical isolates of MRSA, Streptococcus pyogenes, VRE, Acinetobacter baumannii, Citrobacter freundii, Proteus mirabilis, Proteus vulgaris and P. aeruginosa [92]. The ethanolic extracts of Anthocephalus cadamba, Pterocarpus santalinus and Butea monosperma Lam. they have also demonstrated antimicrobial activity against MDR clinical isolates of 10 different microbial species: S. aureus, Acinetobacter sp., C. freundii, Chromobacterium violeceum, E. coli, Klebsiella sp., Proteus sp., P. aeruginosa, Salmonella typhi and Vibrio cholerae $[93,94]$. In the case of B. monosperma Lam., antimicrobial activity was also found in the extract made with hot water from leaf.

\subsubsection{Summary}

As a summary, Table 1 contains all the NPs mentioned above together with their producing organism, type, target bacteria, mechanism of action, main use and references. Figure 4 shows the main molecular targets of the most relevant antimicrobial NPs. 
Table 1. Alphabetically ordered natural products (NPs) with their properties and capabilities. Grey shaded cells mean effectiveness against AMR bacteria. Asterisk (*) means no antimicrobial activity alone.

\begin{tabular}{|c|c|c|c|c|c|c|}
\hline Natural Product & Productor Organism & Type of Organism & Activity Against & Mechanism of Action & Main Use & Reference \\
\hline Actinorhodin & Streptomyces coelicolor & Actinomycete & $\begin{array}{l}\text { Gram-positive, including } \\
\text { multidrug-resistant S. aureus }\end{array}$ & $\begin{array}{l}\text { ROS production inside } \\
\text { bacterial cells }\end{array}$ & Research & [95] \\
\hline Albomycin & $\begin{array}{l}\text { Streptomyces sp. } \\
\text { ATCC } 700974\end{array}$ & Actinomycete & $\begin{array}{l}\text { Gram-negative and Gram-positive, } \\
\text { including MRSA }\end{array}$ & $\begin{array}{l}\text { Seryl t-RNA synthetase } \\
\text { inhibition }\end{array}$ & Medicine & {$[96,97]$} \\
\hline Amphomycin & Streptomyces canus & Actinomycete & $\begin{array}{l}\text { Gram-positive, including MRSA, } \\
\text { VRE and MDR S. pneumoniae }\end{array}$ & $\begin{array}{l}\text { Inhibition of peptidoglycan } \\
\text { and wall teichoic acid } \\
\text { biosyntheses }\end{array}$ & Medicine & [98] \\
\hline Apramycin & $\begin{array}{l}\text { Streptoalloteicus } \\
\text { hindustanus }\end{array}$ & Actinomycete & $\begin{array}{l}\text { Gram-negative, including MDR } \\
\text { A. baumannii and P. areuginosa }\end{array}$ & Inhibition of protein synthesis & Veterinary & [99] \\
\hline Arlomycins & $\begin{array}{l}\text { Streptomyces sp. Tü } \\
6075\end{array}$ & Actinomycete & Gram-positive and Gram-negative & $\begin{array}{l}\text { Inhibition of type I bacterial } \\
\text { signal peptidase }\end{array}$ & $\begin{array}{l}\text { In research for } \\
\text { medical use }\end{array}$ & [100] \\
\hline Aspergillomarasmine A * & A. versicolor & Fungus & $\begin{array}{l}\text { Sensitivizes carbapenem-resistant } \\
\text { bacteria }\end{array}$ & $\begin{array}{l}\text { Inhibition of bacterial } \\
\text { metallo- } \beta \text {-lactamases }\end{array}$ & $\begin{array}{l}\text { In research for } \\
\text { medical use }\end{array}$ & [59] \\
\hline Carbomycin & Streptomyces halstedii & Actinomycete & Gram-positive and Mycoplasma & Inhibition of protein synthesis & Medicine & [101] \\
\hline Cathelicidin-BF & Bungarus fasciatus & Reptile & $\begin{array}{c}\text { Mainly Gram-negative, including } \\
\text { MDR strains }\end{array}$ & $\begin{array}{l}\text { Damage in microbial } \\
\text { cytoplasmic membrane }\end{array}$ & Research & [41] \\
\hline CaTx-II & C. adamanteus & Reptile & Gram-positive and Gram-negative & $\begin{array}{l}\text { Membrane pore formation and } \\
\text { cell wall disintegration }\end{array}$ & Research & [42] \\
\hline Cecropin A & Aedes aegypti & Insect & Gram-negative & $\begin{array}{c}\text { Disruption of the cytoplasmic } \\
\text { membrane }\end{array}$ & $\begin{array}{l}\text { In research for } \\
\text { medical use }\end{array}$ & [102] \\
\hline Cephalosporin & $\begin{array}{l}\text { Cephalosporium } \\
\text { acremonium }\end{array}$ & Fungus & Gram-positive and Gram-negative & Inhibition of cell wall synthesis & Medicine & [103] \\
\hline Cephamycin C & $\begin{array}{l}\text { Streptomyces } \\
\text { clavuligerus }\end{array}$ & Actinomycete & Gram-positive and Gram-negative & Inhibition of cell wall synthesis & $\begin{array}{l}\text { Medicine and } \\
\text { veterinary }\end{array}$ & [104] \\
\hline Chloramphenicol & $\begin{array}{l}\text { Streptomyces } \\
\text { venezuelae }\end{array}$ & Actinomycete & Gram-positive and Gram-negative & Inhibition of protein synthesis & $\begin{array}{l}\text { Medicine and } \\
\text { veterinary }\end{array}$ & [105] \\
\hline Chloroeremomycin & $\begin{array}{l}\text { Amycolatopsis } \\
\text { orientalis }\end{array}$ & Actinomycete & Gram-positive, including VRE & $\begin{array}{l}\text { Inhibition of bacterial cell wall } \\
\text { formation }\end{array}$ & Medicine & [106] \\
\hline Clavulanic acid * & S. clavuligerus & Actinomycete & $\begin{array}{c}\text { Sensitivizes } \beta \text {-lactam-resistant } \\
\text { bacteria }\end{array}$ & $\beta$-lactamase inhibitor & $\begin{array}{l}\text { Medicine and } \\
\text { veterinary }\end{array}$ & [107] \\
\hline Clorobiocin & $\begin{array}{l}\text { Strteptomyces } \\
\text { roseochromogenes }\end{array}$ & Actinomycete & Gram-positive & Inhibitors of DNA gyrase & Medicine & [108] \\
\hline Coumermycin & $\begin{array}{l}\text { Streptomyces } \\
\text { rishiriensis }\end{array}$ & Actinomycete & Mainly Gram-positive & Inhibition of DNA gyrase & Research & {$[109,110]$} \\
\hline Dalbavancin & Nonomuraea sp. & Actinomycete & Gram-positive, including MRSA & Inhibition of cell wall synthesis & Medicine & [111] \\
\hline Daptomycin & $\begin{array}{l}\text { Streptomyces } \\
\text { roseosporus }\end{array}$ & Actinomycete & Gram-positive & $\begin{array}{l}\text { Inhibition of protein, DNA and } \\
\text { RNA synthesis }\end{array}$ & Medicine & [112] \\
\hline Epigallocatechin gallate & $\begin{array}{c}\text { Abundant in Camellia } \\
\text { sinensis }\end{array}$ & Plant & Gram-positive and Gram-negative & $\begin{array}{l}\text { Damage in microbial } \\
\text { cytoplasmic membrane }\end{array}$ & $\begin{array}{l}\text { In research for } \\
\text { medical use }\end{array}$ & {$[81,113]$} \\
\hline
\end{tabular}


Table 1. Cont.

\begin{tabular}{|c|c|c|c|c|c|c|}
\hline Natural Product & Productor Organism & Type of Organism & Activity Against & Mechanism of Action & Main Use & Reference \\
\hline Erythromycin & $\begin{array}{l}\text { Saccharopolyspora } \\
\text { erythraea }\end{array}$ & Actinomycete & Gram-positive & Inhibition of protein synthesis & Medicine & [114] \\
\hline Fosfomycin & $\begin{array}{l}\text { Streptomyces } \\
\text { wedmorensis }\end{array}$ & Actinomycete & Gram-positive and Gram-negative & Inhibition of cell wall synthesis & Medicine & [115] \\
\hline Fusidic acid & Fusidium coccineus & Fungus & Gram-positive, including MRSA & Inhibition of protein synthesis & Medicine & [116] \\
\hline Gentamicin & $\begin{array}{l}\text { Micromonospora } \\
\text { purpurea }\end{array}$ & Actinomycete & Gram-negative & Inhibition of protein synthesis & Medicine & [117] \\
\hline Gramicidin S & B. subtilis & Bacillales & Gram-positive and Gram-negative & $\begin{array}{l}\text { Delocalizes peripheral } \\
\text { membrane proteins involved in } \\
\text { cell division and cell envelope } \\
\text { synthesis }\end{array}$ & Medicine & [118] \\
\hline Hc-CATH & Hydrophis cyanocinctus & Reptile & Gram-positive and Gram-negative & $\begin{array}{l}\text { Damage in microbial } \\
\text { cytoplasmic membrane }\end{array}$ & Research & [119] \\
\hline Hygromycin & $\begin{array}{l}\text { Streptomyces } \\
\text { hygroscopicus }\end{array}$ & Actinomycete & Gram-positive & Inhibition of protein synthesis & $\begin{array}{l}\text { Veterinary and } \\
\text { research }\end{array}$ & [120] \\
\hline Josamycin & $\begin{array}{l}\text { Streptomyces } \\
\text { narbonensis }\end{array}$ & Actinomycete & $\begin{array}{l}\text { Gram-positive, certain } \\
\text { Gram-negative and mycoplasma }\end{array}$ & Inhibition of protein synthesis & Medicine & [121] \\
\hline Kanamycin & $\begin{array}{l}\text { Streptomyces } \\
\text { kanamyceticus }\end{array}$ & Actinomycete & $\begin{array}{l}\text { Mainly Gram-negative and certain } \\
\text { Gram-positive }\end{array}$ & Inhibition of protein synthesis & Medicine & [122] \\
\hline Kirromycin & Streptomyces collinus & Actinomycete & Anaerobes, neisseriae and streptococci & Inhibition of protein synthesis & Research & {$[123,124]$} \\
\hline Lincomycin & $\begin{array}{l}\text { Streptomyces } \\
\text { lincolnensis }\end{array}$ & Actinomycete & Gram-positive & Inhibition of protein synthesis & Medicine & [125] \\
\hline Lipiaramycin & $\begin{array}{l}\text { Dactosporangium } \\
\text { aurantiacum }\end{array}$ & Actinomycete & $\begin{array}{l}\text { Gram-positive and Mycobacterium, } \\
\text { including MDR strains }\end{array}$ & Inhibition of early transcription & Medicine & [126] \\
\hline Melittin & A. mellifera & Insect & $\begin{array}{l}\text { Gram-positive and Gram-negative, } \\
\text { including MDR strains }\end{array}$ & $\begin{array}{l}\text { Damage in microbial } \\
\text { cytoplasmic membrane }\end{array}$ & Medicine & [39] \\
\hline Mirandamycin & $\begin{array}{l}\text { Endophytic fungus } \\
\text { isolated from the twig } \\
\text { of Neomirandea } \\
\text { angularis }\end{array}$ & Fungus & $\begin{array}{c}\text { Gram-negative and Gram-positive, } \\
\text { including MRSA }\end{array}$ & $\begin{array}{l}\text { Inhibition of bacterial quinol } \\
\text { oxidase/ROS production }\end{array}$ & $\begin{array}{l}\text { In research for } \\
\text { medical use }\end{array}$ & [60] \\
\hline Moenomycin & $\begin{array}{l}\text { Streptomyces } \\
\text { ghanaensis }\end{array}$ & Actinomycete & Gram-positive & Inhibition of cell wall synthesis & Veterinary & [127] \\
\hline Morin & Moraceae family & Plant & Gram-positive and Gram-negative & $\begin{array}{l}\text { Inhibition of adhesion to host } \\
\text { tissue and DNA helicase }\end{array}$ & Food technology & [79] \\
\hline Mucroporin & Lychas mucronatus & Arachnid & $\begin{array}{l}\text { Gram-positive and Gram-negative, } \\
\text { including MDR strains }\end{array}$ & $\begin{array}{l}\text { Damage in microbial } \\
\text { cytoplasmic membrane }\end{array}$ & Research & {$[128]$} \\
\hline Neomycin & S. fradiae & Actinomycete & Gram-positive and Gram-negative & Inhibition of ribonuclease $\mathrm{P}$ & Medicine & [129] \\
\hline Orthoformimycin & S. griseus & Actinomycete & Gram-positive and Gram-negative & Inhibition of protein synthesis & $\begin{array}{l}\text { In research for } \\
\text { medical use }\end{array}$ & {$[49]$} \\
\hline Oxytetracycline & Streptomyces rimosus & Actinomycete & Gram-positive and Gram-negative & Inhibition of protein synthesis & Aquaculture & [130] \\
\hline
\end{tabular}


Table 1. Cont.

\begin{tabular}{|c|c|c|c|c|c|c|}
\hline Natural Product & Productor Organism & Type of Organism & Activity Against & Mechanism of Action & Main Use & Reference \\
\hline Penicillins & Penicillium crysogenum & Fungus & Gram-positive and Gram-negative & $\begin{array}{l}\text { Inhibition of cell wall synthesis } \\
\text { and activation of the } \\
\text { endogenous autolytic system }\end{array}$ & Medicine & [131] \\
\hline Pleuromutalin & Clitopilus scyphoides & Fungus & $\begin{array}{c}\text { Gram-positive, Gram-negative and } \\
\text { Mycoplasma }\end{array}$ & Inhibition of translation & Veterinary & [132] \\
\hline Polymyxin & Paenibacillus polymyxa & Bacillales & $\begin{array}{l}\text { Mainly Gram-negative (including } \\
\text { MDR) and certain Gram-positive }\end{array}$ & $\begin{array}{l}\text { Disruption of the cytoplasmic } \\
\text { membrane }\end{array}$ & Medicine & [133] \\
\hline Pristinamycin & $\begin{array}{l}\text { Streptomyces } \\
\text { pristinaespiralis }\end{array}$ & Actinomycete & Gram-positive, including MRSA & Inhibition of protein synthesis & Medicine & [134] \\
\hline Punicalagin & $\begin{array}{l}\text { Abundant in Punica } \\
\text { granatum }\end{array}$ & Plant & Gram-positive and Gram-negative & $\begin{array}{l}\text { Damage in microbial } \\
\text { cytoplasmic membrane }\end{array}$ & Food technology & {$[80,84]$} \\
\hline Quercetin & Ubiquitous in plants & Plant & Gram-positive and Gram-negative & $\begin{array}{c}\text { Damage in the structure of the } \\
\text { bacterial cell wall and cell } \\
\text { membrane }\end{array}$ & $\begin{array}{l}\text { In research for } \\
\text { medical use }\end{array}$ & [135] \\
\hline Ramoplanin & $\begin{array}{c}\text { Actinoplanes sp. ATCC } \\
33076\end{array}$ & Actinomycete & $\begin{array}{c}\text { Gram-positive, including MDR } \\
\text { strains }\end{array}$ & Inhibition of cell wall synthesis & Medicine & [136] \\
\hline Resveratrol & $\begin{array}{l}\text { Abundant in grapes, } \\
\text { berries and legumes }\end{array}$ & Plant & $\begin{array}{c}\text { Gram-positive and Gram-negative, } \\
\text { including MDR strains }\end{array}$ & $\begin{array}{l}\text { Inhibition of motility, adhesion, } \\
\text { quorum sensing, biofilm } \\
\text { formation, flagellar gene } \\
\text { expression and hemolytic } \\
\text { activity }\end{array}$ & Medicine & [75] \\
\hline Rifamycin & $\begin{array}{l}\text { Amycolatopsis } \\
\text { mediterranei }\end{array}$ & Actinomycete & $\begin{array}{l}\text { Gram-positive and certain } \\
\text { Gram-negative }\end{array}$ & $\begin{array}{l}\text { Inhibition of DNA-dependent } \\
\text { RNA synthesis }\end{array}$ & Medicine & [137] \\
\hline Ristocetin A & A. orientalis & Actinomycete & Gram-positive, including MRSA & Inhibition of cell wall synthesis & Medicine & [138] \\
\hline Royalisin & Apis melifera & Insect & Mainly gram-positive & $\begin{array}{c}\text { Damage in the structure of the } \\
\text { bacterial cell wall and cell } \\
\text { membrane }\end{array}$ & Research & [37] \\
\hline Skyllamycins & $\begin{array}{l}\text { Streptomyces sp. } \\
\quad \text { KY } 11784\end{array}$ & Actinomycete & Gram-positive & Inhibition of biofilm formation & $\begin{array}{l}\text { In research for } \\
\text { medical use }\end{array}$ & [139] \\
\hline SlLebocin1 & Spodoptera litura & Insect & Gram-positive and Gram-negative & $\begin{array}{l}\text { Damage in microbial } \\
\text { cytoplasmic membrane or cell } \\
\text { division inhibition }\end{array}$ & Research & [140] \\
\hline Spectinomycin & Streptomyces spectabilis & Actinomycete & Gram-positive and Gram-negative & Inhibition of protein synthesis & Medicine & [141] \\
\hline Spiramycin & $\begin{array}{l}\text { Streptomyces } \\
\text { ambofaciens }\end{array}$ & Actinomycete & Gram-positive and Gram-negative & Inhibition of protein synthesis & Medicine & [142] \\
\hline Streptothricin & $\begin{array}{l}\text { Streptomyces } \\
\text { (multiple species) }\end{array}$ & Actinomycete & Gram-positive and Gram-negative & Inhibition of protein synthesis & $\begin{array}{l}\text { Veterinary and plant } \\
\text { production }\end{array}$ & [143] \\
\hline
\end{tabular}


Table 1. Cont.

\begin{tabular}{|c|c|c|c|c|c|c|}
\hline Natural Product & Productor Organism & Type of Organism & Activity Against & Mechanism of Action & Main Use & Reference \\
\hline Teicoplanin & $\begin{array}{l}\text { Actinoplanes } \\
\text { teichomyceticus }\end{array}$ & Actinomycete & Gram-positive, including MRSA & $\begin{array}{l}\text { Inhibition of bacterial cell wall } \\
\text { synthesis }\end{array}$ & Medicine & [144] \\
\hline Teixobactin & Eleftheria terrae & Betaproteobacteria & Gram-positive, including MRSA & $\begin{array}{l}\text { Causes digestion of the cell } \\
\text { wall by autolysins }\end{array}$ & Medicine & [55] \\
\hline Tetracycline & Streptomyces rimosus & Actinomycete & Gram-positive and Gram-negative & Inhibition of protein synthesis & Medicine & [145] \\
\hline Thienamycin & Streptomyces cattleya & Actinomycete & Gram-positive and Gram-negative & $\begin{array}{c}\text { Inhibition of bacterial cell wall } \\
\text { synthesis }\end{array}$ & $\begin{array}{l}\text { Derivates used in } \\
\text { medicine }\end{array}$ & [146] \\
\hline Thiostrepton & Streptomyces azureus & Actinomycete & Gram-positive and Gram-negative & Inhibition of protein synthesis & $\begin{array}{l}\text { Veterinary and } \\
\text { research }\end{array}$ & [147] \\
\hline Tobramycin & $\begin{array}{l}\text { Streptoalloteicus } \\
\text { hindustanus }\end{array}$ & Actinomycete & Gram-negative & $\begin{array}{l}\text { Inhibition of protein synthesis } \\
\text { and membrane destabilization }\end{array}$ & Medicine & [148] \\
\hline Tunicamycin & $\begin{array}{l}\text { Streptomyces } \\
\text { chartreusis }\end{array}$ & Actinomycete & Gram-positive & $\begin{array}{l}\text { Inhibition of peptidoglycan } \\
\text { and lipopolysaccharide } \\
\text { synthesis }\end{array}$ & Research & [149] \\
\hline Tylosin & S. fradiae & Actinomycete & Gram-positive and Mycoplasma & Inhibition of protein synthesis & Veterinary & {$[150]$} \\
\hline Vancomycin & S. orientalis & Actinomycete & Gram-positive, including MRSA & $\begin{array}{c}\text { Inhibition of bacterial cell wall } \\
\text { synthesis }\end{array}$ & Medicine & [45] \\
\hline Vejovine & V. mexicanus & Arachnid & Gram-negative, including MDR & $\begin{array}{l}\text { Damage in microbial } \\
\text { cytoplasmic membrane }\end{array}$ & Research & [44] \\
\hline Viomycin & Streptomyces sp. 11861 & Actinomycete & MDR Mycobacterium & Inhibition of protein synthesis & Medicine & [151] \\
\hline Virginiamycin & Streptomyces virginiae & Actinomycete & Gram-positive & Inhibition of protein synthesis & $\begin{array}{l}\text { Agriculture and } \\
\text { industry }\end{array}$ & [152] \\
\hline
\end{tabular}




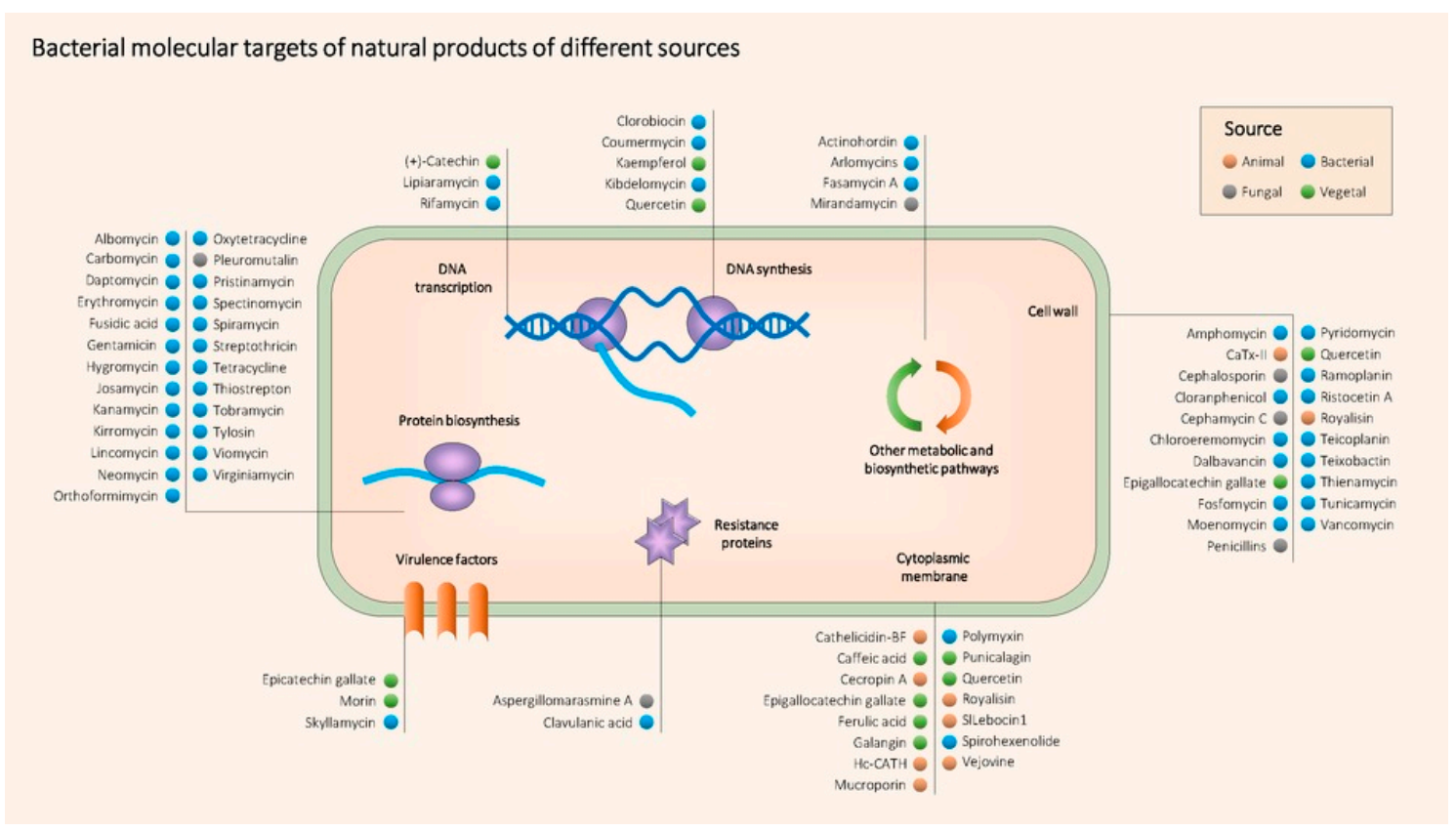

Figure 4. Main known molecular targets of antimicrobial NPs described in this review.

\subsection{Antibiotics and Plant Compounds Combinations to Get around AMR}

The synergic combination of antibiotics and phytochemicals represents a promising strategy with numerous clinical and developmental benefits. Some plant compounds have direct antimicrobial activity against antibiotic-resistant bacteria, while others can sensitize resistant bacteria against antibiotics, reversing the resistance as mentioned and exemplified in the previous section. Some of these NPs can enhance the effect of antibiotics in different ways, such as facilitating their entry into the cell by destabilizing the cytoplasmic membrane [153,154], inhibiting efflux pumps (EPs) [155] or dispersing biofilms [156] among other mechanisms of action (Figure 4). Some of the synergistic interactions between phytochemicals and antibiotics include increased efficiency, lower antibiotic doses, reduced side effects, increased bioavailability and increased stability [157]. The multidimensional and multifactorial activity of phytochemicals studied by network pharmacology is crucial for synergy with clinical antibiotics, opening the door to many different potential combinations. Moreover, the use of molecules that have already passed the relevant clinical controls, as in the case of antibiotics, in combination with innocuous natural compounds facilitates the process of research and development of new potential therapies [158].

There is clear evidence of NPs capable of inhibiting efflux pumps of AMR bacteria, specifically, phytochemicals. These molecules can inhibit various efflux pumps in different pathogenic bacterial species, both Gram-positive and Gram-negative. As an example, the NorA efflux pump of S. aureus SA-1199-B has been effectively inhibited using baicalein plant molecules [159], capsaicin [160], indirubin [161], kaempferol rhamnoside [162] and olympicin A [163]. NorA of S. aureus NCTC 8325-4 was inhibited using sarothrin [164]. Cumin demonstrated antimicrobial activity on its own and also resistance modulation properties against MRSA by inhibiting LmrS efflux pump [155]. Plant molecules inhibiting the ethidium bromide efflux pump (EtBr) have also been found: $1^{\prime}-\mathrm{S}-1^{\prime}$-acetoxyeugenol acetate inhibits it in Mycobacterium smegmatis [165], catechol and catharanthine inhibits it in P. aeruginosa [166,167] and galotannins inhibit it in MDR uropathogenic E. coli [168]. The Yojl efflux pump of MDR E. coli has been shown to be inhibited by molecules such as 4-hydroxy-tetralone, ursolic acid and its derivatives [169] and lysergol [170]. Berberine and palmatine inhibit MexAB-OprM from clinical isolates of MDR P. aeruginosa [171]. There are also complete extracts of plants with EPs inhibitory activity with clear synergistic effects with antibiotics in the treatment of MDR bacterial infections. The extract made from Rhus coriaria seeds have shown an obvious synergistic effect with 
oxytetracycline, penicillin G, cephalexin, sulfadimethoxine and enrofloxacin against MDR clinical isolates of P. aeruginosa. This effect is mainly attributed to the inhibitory capacity of EPs of the phytochemicals present in the extract [172]. The activity of these plant molecules as inhibitors of microbial efflux pumps can act as restorers of antimicrobial susceptibility and open the door to combined antibiotic treatments, since these could exert their action more easily by not being expelled from the bacterial interior, allowing relive obsolete or discarded therapies due to this resistance mechanism [173]. A catechin, (-)-epigallocatechin gallate (EGCg), has shown sensitizing activity in S. aureus against tetracycline by inhibiting EPs such as Tet (K), increasing intracellular retention of the antibiotic and enhancing its effect [174]. Stilbenes also act as EPs inhibitors against antibiotic-resistant Arcobacter butzleri, reducing its resistance. Resveratrol and pinosylvin have also shown activity as resistance modulators being able to even reverse the resistance completely [175].

There are studies that state that certain polyphenols, such as catechins, can enter deeply into the structure of the lipid bilayer of bacterial membranes, causing significant thermotropic changes. Lipophilic hydrocarbons present in plant extracts are known to destabilize the cellular structure of the cytoplasmic membrane, increase its permeability and interact with hydrophobic portions of proteins [176]. This could explain the potentiation in the effect of certain antibiotics against resistant bacteria, as these compounds could increase antibiotic intake and interact with resistance proteins, hindering their activity. Specifically, (-)-epicatechin gallate $(\mathrm{ECg})$ has a great affinity for the staphylococcal wall and its binding to it produces biophysical changes in it that are capable of dispersing the biosynthetic machinery responsible for resistance to $\beta$-lactam antibiotics [177]. This activity would explain the restoration of the sensitivity of bacteria resistant to traditional antibiotics through the use of polyphenolic compounds capable of interacting with bacterial membranes, as in the case of catechins capable of sensitizing MRSA against oxacillin and other $\beta$-lactam antibiotics thanks to its ability to integrate and interact with the cell membrane [178,179].

Plant extracts are also capable of exert antimicrobial activity against AMR bacteria and synergize with antibiotics. For instance, extracts of Duabanga grandiflora can restore MRSA's sensitivity to ampicillin. The mechanism proposed by the researchers is that the components of this extract can decrease the expression of the mecA gene that gives rise to the resistance protein PBP2a [180]. Extracts of Acacia nilotica, Syzygium aromaticum and Cinnamum zeylanicum exhibited antimicrobial capacity against a panel of AMR bacteria including clinical isolates and ATCC strains. Extract of A. nilotica showed MIC values as low as $9.75 \mu \mathrm{g} / \mathrm{mL}$ against K. pneumoniae ATCC-700803, Salmonella typhimurium ATCC-13311 and E. faecalis ATCC-29212 [181]. Extracts of Salvia spp. and Matricaria recutita have shown great synergy with the antibiotic oxacillin [182]. The multifactorial and multi-target character of the compounds that make up plant extracts can hinder the development of resistance by bacteria [80]. The molecular promiscuity of polyphenols, their multarget activity, the possibility of obtaining complex extracts containing multiple different polyphenols, and their synergistic effect in combined use with clinical antibiotics make natural antimicrobial compounds of plant origin ideal tools to be studied from the point of view of network pharmacology in the future. The evidence found in the combination studies between plant extracts and clinical antibiotics shows a synergistic enhancement that may be key to the fight against AMR bacteria. Although the development of new synthetic antibiotics is essential to continue the fight, the sensitization of resistant bacteria by phytochemicals is also crucial to achieving effective and long-lasting therapies [158].

Infections caused by bacteria forming biofilms are extremely difficult to treat and are much less susceptible to antibiotics $[183,184]$. One way to enhance the effect of an antimicrobial agent is to disrupt the biofilm that certain resistant bacteria form. Studies on P. aeruginosa showed that many natural products can inhibit biofilm formation or disrupt the previously formed biofilm: alginate lyase [185], ursolic acid [186], zingerone [187], cranberry proanthocyanidins [188], casbane diterpene [189], manoalide [190], solenopsin A [191], catechin [192], naringenin [193], ajoene [194], rosmarinic acid [195], eugenol [196], bergamottin [197], emodin [198] and baicalein [199] among others. These natural biofilm disrupting compounds could be a very valuable tool to be incorporated into joint 
therapies with traditional antibiotics when treating infections caused by AMR bacteria. For example, cranberry proanthocyanidins enhanced the activity of gentamicin in an in vivo model of infection using Galleria mellonella [188]. In addition, some of these compounds have intrinsic antimicrobial activity on its own, which could further increase the potency of the treatment.

\subsection{Development of Resistance to Natural Products}

Historically, bacteria have managed to develop resistance to a greater or lesser extent against most antimicrobial agents used in medicine. Nevertheless, the ability of bacteria to develop a resistance mechanism against natural products is not well documented [200]. Due to the huge chemical and structural diversity among antimicrobial products of natural origin, it is often stated the difficulty for bacteria to avoid the action of NPs [201,202]. However, there are some recent studies that suggest that bacteria can develop certain levels of resistance against plant compounds, especially enteric bacteria [203]. The mechanisms of resistance behind these observations remain unknown and literature on the subject is scarce.

There are multiple mechanisms by which a bacterium can get rid of the action of an antimicrobial molecule: target alterations, expulsion or modification of the antibiotic, inactivation, reduced permeability and biofilm formation among others [204]. These resistant mechanisms can be spontaneously developed (mutations) or acquired (by transduction, transfection or conjugation processes) as shown in Figure 5. Understanding the mechanism by which bacteria can circumvent the action of antibiotics and how they acquire these capabilities is crucial to developing effective and lasting therapies.

\section{Antimicrobial Resistance Mechanisms Resistance Acquisition Mechanisms}

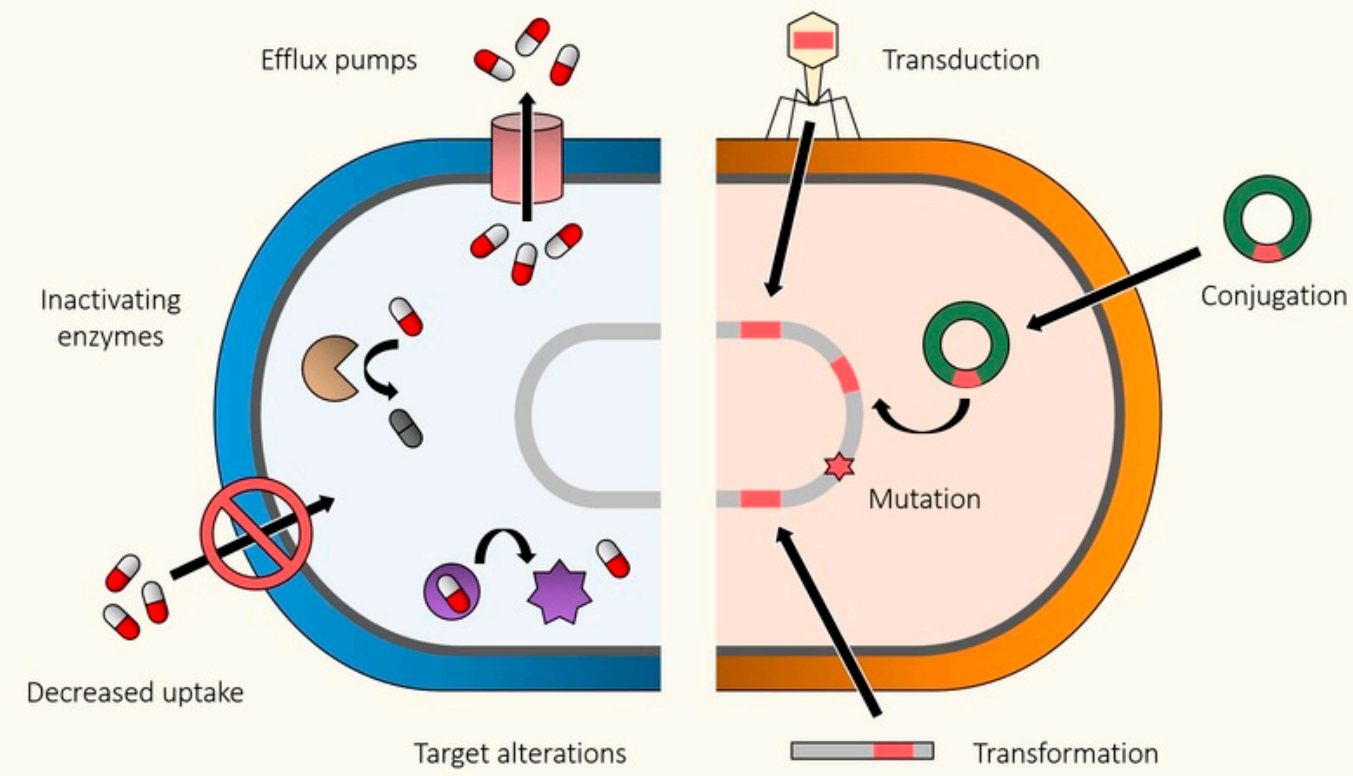

Figure 5. Antimicrobial resistance mechanisms and acquisition mechanisms in bacteria.

Depending on their properties, some products are more susceptible than others to the appearance of bacteria resistant to them. Molecules that attack highly conserved targets are less conducive to the appearance of bacteria with mutations in said targets that confer resistance to the antimicrobial in question, since modifying one or more fundamental routes or targets can imply an unbearable fitness cost for the bacteria [205]. 
On the other hand, molecules against less conserved molecular targets are more likely to promote the development of resistance mechanisms against them. Modification of less evolutionarily conserved or non-essential targets is easier for bacteria to assimilate since they have greater flexibility to modify the molecular target or adapt their metabolism without paying a high fitness cost. Although the acquisition of antimicrobial resistance mechanisms is often accompanied by reduced fitness in the absence of a selective environment, this loss of adaptive efficacy can be counteracted by compensatory mutations or modifications in epistasis [206].

Thanks to the multifactorial nature of the molecular promiscuity of naturally occurring antimicrobial compounds, bacteria experience difficulties in changing several molecular targets simultaneously [80]. Multiple simultaneous molecular changes in a bacterium to overcome the action of a multifactorial antimicrobial agent would very negatively affect its metabolism, that is, it would have a high fitness cost potentially unacceptable for its development. Likewise, mutations that carry a high fitness cost are less likely to persist in bacterial populations once the selective pressure disappears [207]. This cost would be higher if the molecular targets of the antimicrobial were highly evolutionary conserved molecules or routes, since they would be more difficult to change while maintaining the metabolic efficiency necessary for survival and competition with other living beings. Furthermore, there are studies that affirm that many of the natural antimicrobial compounds attack macromolecular structures such as the membrane or the bacterial wall and that this fact could hinder the appearance of resistance, given that they are very difficult targets to vary as a whole [208,209].

Despite the multiple possible mechanisms for acquiring existing resistances, the use of new technologies in NPs can help prevent their development. Based on new laboratory bacterial culture techniques, it has been possible to identify and isolate interesting natural compounds such as teixobactin. This molecule displays a mechanism of action that is capable of using the bacteria's own machinery to kill itself, in a similar way to how vancomycin, a really successful antibiotic, works. No resistant mutants have been found against teixobactin. Theoretically, the generation of resistant mutants to this compound is difficult, since its target is very conserved among the eubacteria, in addition to being exposed in the outermost part of Gram-positive bacteria. In addition, as teixobactin is produced by a Gram-negative bacterium, the molecule cannot re-enter the cell and exert its action due to the presence of the outer envelope characteristic of Gram-negative bacteria. This fact is crucial in the process of the eventual development of resistance, since the producing microorganism does not use a different metabolic route to avoid the action of the antibiotic it produces. Thus, in the absence of an intrinsic resistance mechanism in the producer, horizontal transfer of resistance genes to other species susceptible to teixobactin cannot occur [55].

Vancomycin, discovered in 1958, enjoyed a period of 30 years in which no bacterium resistant to its antibiotic action was identified, thanks to its potent and unusual mechanism of action. However, during the last 20 years, S. aureus strains resistant to this antibiotic have been detected [210]. One of the resistance mechanisms identified is the incorporation of D-Ala-D-lactate instead of the usual D-Ala-D-Ala at the dipeptide termini of nascent peptidoglycan, considerably reducing its binding affinity and formation disruption capacity of the bacterial wall. Other resistant strains identified have a thicker cell wall with free D-Ala-D-Ala ends that can sequester vancomycin and removing it from the place where the biosynthesis of the wall occurs [211]. Despite the emergence of these and other resistance mechanisms, researchers are currently working on vancomycin derivatives that have promising qualities that allow them to circumvent these resistance mechanisms and exert their antibiotic action. An example of this is the discovery of a new vancomycin resistance mechanism mediated by the activity of Atl amidase. This inhibition produces cellular morphological changes that reduce the action of vancomycin on the main target in the biosynthesis of the wall, increasing the tolerance of the pathogen against the antibiotic without any changes at the genetic level. The discovery of this target opens the door to the design of derivatives of vancomycin with a reduced affinity for Atl, resulting in greater efficacy against MRSA [46]. Another resistance mechanism found in S. aureus 
against vancomycin is based on the thickening of the bacterial wall, which slows the penetration of vancomycin into the bacteria [212].

A possible strategy to prevent or slow the appearance of antimicrobial-resistant bacteria is the combined use of various agents that act against different molecular targets. In this way, the bacteria will have to adopt different resistance mechanisms, which would imply a greater and less likely adaptive cost. This hypothesis could support the use of plant extracts and essential oils in traditional medicine used for millennia, since these may be composed of dozens of different phytochemicals with different mechanisms of action. The combined activity of these molecules would hinder bacterial adaptation and extend the therapeutic shelf life of antimicrobial plant extracts.

Although the idea of the difficulty of acquiring resistance against complex plant extracts is widespread, some studies go in the opposite direction. It has been observed that certain antimicrobial extracts used against enterobacteria isolated from geckos from various environments in India have reduced effectiveness. The authors attribute this resistance to the variability and changing environment that has shaped the isolates collected and used in the assay. They suggest that exposure of geckos to medicinal plants may have caused a process of selecting the bacteria present in them, resulting in strains more resistant to plant compounds [203]. Mechanisms of possible resistance are not mentioned.

\subsection{New Methodologies to Find Antimicrobial Compounds against AMR Bacteria}

Currently, there are many methodologies capable of having a very positive impact on the discovery of new natural molecules with antimicrobial capacity against AMR bacteria. Some of these methodologies are the use of -omics technologies, network pharmacology, synergy studies and in silico trials.

Thanks to the -omics technologies, today it is known that genomes of bacteria such as actinomycetes are much more complex than previously thought in the mid-twentieth century and that there are multiple secondary metabolite gene clusters (SMGCs) that could produce new NPs. It is estimated that under the conditions of the classic fermentation studies for NP isolation, less than $10 \%$ of the SMGCs are active, which could be activated using genetic techniques and varying the culture conditions to reveal potential new NPs hidden inside of the "biosynthetic dark matter" [213]. By combining the progressive lowering of the massive sequencing of bacterial genomes and the advancement of the analysis and prediction software it will be possible to identify new SMGCs and their products [214,215]. The discovery and deepening of knowledge of NP-producing modular macroenzymes such as non-ribosomal peptide synthetases and polyketyde synthetases open the door to new NPs production strategies based on combinatorial biosynthesis [15]. Scientists now have greater access to soil samples and other potential sources of NPs, which significantly increases the likelihood of finding new compounds. The use of non-laboratory-dependent metagenomic techniques and the heterologous expression of DNA extracted directly from complex samples will allow the identification and production of new NPs hitherto unknown or impossible to produce [216].

Other new technologies such as molecular docking or virtual simulations open the door to the effective discovery of new natural antimicrobial compounds unknown so far using computers [76,217]. In silico assays allow hundreds of thousands of molecules to be screened to efficiently select leaders, greatly reducing the cost of new drug development processes. Prediction via molecular docking or virtual simulation makes it possible to predict the interactions of a molecule with its target, obtaining huge amounts of valuable information and allowing the screening of drug libraries in a short time if the necessary computing capacity is available [218,219].

Emerging studies based on network pharmacology that expand the classic single-ligand-target viewpoint provide excellent opportunities for the development of new antimicrobial compounds. The study of the network pharmacology of phytochemicals based on their molecular promiscuity and multi-target capacity can help to better understand their antimicrobial mechanisms of action and to develop more effective therapies [220]. In turn, this point also has a positive impact on synergy studies 
between antibiotics and phytochemicals such as those described in the previous sections, and they are currently showing such good results.

\section{Conclusions and Future Perspectives}

In conclusion, most NPs do not have sufficient therapeutic power to perform monotherapies based on them against antibiotic resistant bacteria, however, their joint application in combination therapy with traditional antibiotics could contribute to enhance their effect, reduce their dosage, side effects and improve its pharmacokinetics and pharmacodynamics properties. Natural antimicrobial products offer a promising avenue of study in the field of antibiotic development thanks to their unique properties, natural availability and enormous chemical diversity. The prospects in the discovery of new NPs with antibiotic activity are very positive. There is a tendency to revise the traditional sources of NPs that offered such good results during the "Golden Age" [221]. The use of new technologies and applications of non-existent knowledge during that age opens the door to the second era of massive discovery of molecules with remarkable and novel biological activity against AMR bacteria.

Author Contributions: Conceptualization, F.J.Á.-M., E.B.-C. and V.M.; methodology, F.J.Á.-M.; investigation, F.J.Á.-M.; data curation, F.J.Á.-M., E.B.-C. and V.M.; writing—original draft preparation, F.J.Á.-M.; writing-review and editing, F.J.Á.-M., E.B.-C. and V.M.; visualization, F.J.Á.-M., E.B.-C. and V.M.; supervision, E.B.-C. and V.M.; project administration, E.B.-C. and V.M.; funding acquisition, E.B.-C. and V.M. All authors have read and agreed to the published version of the manuscript.

Funding: We thank grants RTI2018-096724-B-C21 from the Spanish Ministry of Economy and Competitiveness (MINECO); PROMETEO/2016/006, from Generalitat Valenciana; CIBER (CB12/03/30038, Fisiopatologia de la Obesidad y la Nutricion, CIBERobn, Instituto de Salud Carlos III) and the "Aid for the support to the training of research staff" of the Miguel Hernández University of Elche (resolution 0236/17).

Conflicts of Interest: The authors declare no conflict of interest.

\section{References}

1. IHME; GBD. The Review on Antimicrobial Resistance. Available online: https://amr-review.org/ (accessed on 20 May 2020).

2. Goossens, H. The chennai declaration on antimicrobial resistance in india. Lancet Infect. Dis. 2013, 13, 105-106. [CrossRef]

3. Sultan, I.; Rahman, S.; Jan, A.T.; Siddiqui, M.T.; Mondal, A.H.; Haq, Q.M.R. Antibiotics, resistome and resistance mechanisms: A bacterial perspective. Front. Microbiol. 2018, 9, 2066. [CrossRef] [PubMed]

4. Daubin, V.; Szollosi, G.J. Horizontal gene transfer and the history of life. Cold Spring Harb Perspect. Biol. 2016, 8, a018036. [CrossRef] [PubMed]

5. Munita, J.M.; Arias, C.A. Mechanisms of antibiotic resistance. Microbiol. Spectr. 2016, 4, 481-511. [CrossRef]

6. Wong, A. Epistasis and the evolution of antimicrobial resistance. Front. Microbiol. 2017, 8, 246. [CrossRef]

7. Clarke, L.; Pelin, A.; Phan, M.; Wong, A. The effect of environmental heterogeneity on the fitness of antibiotic resistance mutations in Escherichia coli. Evol. Ecol. 2020, 34, 379-390. [CrossRef]

8. Davies, J.; Davies, D. Origins and evolution of antibiotic resistance. Microbiol. Mol. Biol. Rev. 2010, 74, 417-433. [CrossRef]

9. Hiltunen, T.; Virta, M.; Laine, A.L. Antibiotic resistance in the wild: An eco-evolutionary perspective. Philos. Trans. R. Soc. B Biol. Sci. 2017, 372, 20160039. [CrossRef]

10. Wong, A. Unknown risk on the farm: Does agricultural use of ionophores contribute to the burden of antimicrobial resistance? mSphere 2019, 4, e00433-19. [CrossRef]

11. Machowska, A.; Stalsby Lundborg, C. Drivers of irrational use of antibiotics in Europe. Int. J. Environ. Res. Public Health 2018, 16, 27. [CrossRef]

12. Towse, A.; Hoyle, C.K.; Goodall, J.; Hirsch, M.; Mestre-Ferrandiz, J.; Rex, J.H. Time for a change in how new antibiotics are reimbursed: Development of an insurance framework for funding new antibiotics based on a policy of risk mitigation. Health Policy 2017, 121, 1025-1030. [CrossRef] [PubMed]

13. Sabtu, N.; Enoch, D.A.; Brown, N.M. Antibiotic resistance: What, why, where, when and how? Br. Med. Bull. 2015, 116, 105-113. [CrossRef] [PubMed] 
14. EUCAST. Determination of minimum inhibitory concentrations (mics) of antibacterial agents by broth dilution. Clin. Microbiol. Infect. 2003, 9, 1-7.

15. Katz, L.; Baltz, R.H. Natural product discovery: Past, present, and future. J. Ind. Microbiol. Biotechnol. 2016, 43, 155-176. [CrossRef] [PubMed]

16. Berdy, J. Thoughts and facts about antibiotics: Where we are now and where we are heading. J. Antibiot. 2012, 65, 385-395. [CrossRef] [PubMed]

17. Bar-On, Y.M.; Phillips, R.; Milo, R. The biomass distribution on earth. Proc. Natl. Acad. Sci. USA 2018, 115, 6506-6511. [CrossRef]

18. Muthamilarasan, M.; Prasad, M. Plant innate immunity: An updated insight into defense mechanism. J. Biosci. 2013, 38, 433-449. [CrossRef]

19. Tapsell, C.L.; Hemphill, I.; Cobiac, L. Health benefits of herbs and spices: The past, the present, the future. MJA 2006, 185, S1-S24. [CrossRef]

20. Leja, K.B.; Czaczyk, K. The industrial potential of herbs and spices-A mini review. Acta Sci. Pol. Technol. Aliment. 2016, 15, 353-365. [CrossRef]

21. Franke, H.; Scholl, R.; Aigner, A. Ricin and ricinus communis in pharmacology and toxicology-from ancient use and "papyrus ebers" to modern perspectives and "poisonous plant of the year 2018". Naunyn Schmiedebergs Arch. Pharm. 2019, 392, 1181-1208. [CrossRef]

22. Dwivedi, G.; Shridhar, D. Sushruta-The clinician-Teacher par excellence. Indian J. Chest Dis. Allied Sci. 2007, 49, 243-244.

23. Aggarwal, B.B.; Sundaram, C.; Malani, N.; Ichikawa, H. Curcumin: The indian solid gold. In The Molecular Targets and Therapeutic Uses of Curcumin in Health and Disease; Aggarwal, B.B., Surh, Y.-J., Shishodia, S., Eds.; Springer: Boston, MA, USA, 2007; Volume 595.

24. Woodruff, H.B. Selman A. Waksman, winner of the 1952 nobel prize for physiology or medicine. Appl. Environ. Microbiol. 2014, 80, 2-8. [CrossRef] [PubMed]

25. Kurt, E.L. Small World Initiative. Available online: http://www.smallworldinitiative.org/ (accessed on 5 August 2020).

26. Gould, K. Antibiotics: From prehistory to the present day. J. Antimicrob. Chemother. 2016, 71, 572-575. [CrossRef] [PubMed]

27. Silver, L. Natural products as a source of drug leads to overcome drug resistance. Future Microbiol. 2015, 10, 1711-1718. [CrossRef] [PubMed]

28. Barrajon-Catalan, E.; Menendez-Gutierrez, M.P.; Falco, A.; Carrato, A.; Saceda, M.; Micol, V. Selective death of human breast cancer cells by lytic immunoliposomes: Correlation with their her2 expression level. Cancer Lett. 2010, 290, 192-203. [CrossRef] [PubMed]

29. Falco, A.; Barrajón-Catalán, E.; Menéndez-Gutiérrez, M.P.; Coll, J.; Micol, V.; Estepa, A. Melittin-loaded immunoliposomes against viral surface proteins, a new approach to antiviral therapy. Antivir. Res. 2013, 97, 218-221. [CrossRef] [PubMed]

30. Yi, H.Y.; Chowdhury, M.; Huang, Y.D.; Yu, X.Q. Insect antimicrobial peptides and their applications. Appl. Microbiol. Biotechnol. 2014, 98, 5807-5822. [CrossRef]

31. Lee, M.; Bang, K.; Kwon, H.; Cho, S. Enhanced antibacterial activity of an attacin-coleoptericin hybrid protein fused with a helical linker. Mol. Biol. Rep. 2013, 40, 3953-3960. [CrossRef]

32. Ali, S.M.; Siddiqui, R.; Ong, S.K.; Shah, M.R.; Anwar, A.; Heard, P.J.; Khan, N.A. Identification and characterization of antibacterial compound(s) of cockroaches (Periplaneta americana). Appl. Microbiol. Biotechnol. 2017, 101, 253-286. [CrossRef]

33. Arora, S.; Baptista, C.; Lim, C.S. Maggot metabolites and their combinatory effects with antibiotic on Staphylococcus aureus. Ann. Clin. Microbiol. Antimicrob. 2011, 10, 6. [CrossRef]

34. Kwakman, P.H.; Te Velde, A.A.; de Boer, L.; Vandenbroucke-Grauls, C.M.; Zaat, S.A. Two major medicinal honeys have different mechanisms of bactericidal activity. PLoS ONE 2011, 6, e17709. [CrossRef] [PubMed]

35. Zabaiou, N.; Fouache, A.; Trousson, A.; Baron, S.; Zellagui, A.; Lahouel, M.; Lobaccaro, J.A. Biological properties of propolis extracts: Something new from an ancient product. Chem. Phys. Lipids 2017, 207, 214-222. [CrossRef] [PubMed]

36. Rahman, M.M.; Richardson, A.; Sofian-Azirun, M. Antibacterial activity of propolis and honey against Staphylococcus aureus and Escherichia coli. Afr. J. Microbiol. Res. 2010, 4, 1872-1878. 
37. Bilikova, K.; Huang, S.C.; Lin, I.P.; Simuth, J.; Peng, C.C. Structure and antimicrobial activity relationship of royalisin, an antimicrobial peptide from royal jelly of Apis mellifera. Peptides 2015, 68, 190-196. [CrossRef]

38. Fratini, F.; Cilia, G.; Mancini, S.; Felicioli, A. Royal jelly: An ancient remedy with remarkable antibacterial properties. Microbiol. Res. 2016, 192, 130-141. [CrossRef]

39. Memariani, H.; Memariani, M.; Shahidi-Dadras, M.; Nasiri, S.; Akhavan, M.M.; Moravvej, H. Melittin: From honeybees to superbugs. Appl. Microbiol. Biotechnol. 2019, 103, 3265-3276. [CrossRef]

40. Sagheer, M.; Siddiqui, R.; Iqbal, J.; Khan, N.A. Black cobra (Naja naja karachiensis) lysates exhibit broad-spectrum antimicrobial activities. Pathog. Glob. Health 2014, 108, 129-136. [CrossRef]

41. Wang, Y.; Hong, J.; Liu, X.; Yang, H.; Liu, R.; Wu, J.; Wang, A.; Lin, D.; Lai, R. Snake cathelicidin from Bungarus fasciatus is a potent peptide antibiotics. PLoS ONE 2008, 3, e3217. [CrossRef]

42. Samy, R.P.; Kandasamy, M.; Gopalakrishnakone, P.; Stiles, B.G.; Rowan, E.G.; Becker, D.; Shanmugam, M.K.; Sethi, G.; Chow, V.T. Wound healing activity and mechanisms of action of an antibacterial protein from the venom of the eastern diamondback rattlesnake (Crotalus adamanteus). PLoS ONE 2014, 9, e80199. [CrossRef]

43. Lin, F.Y.; Gao, Y.; Wang, H.; Zhang, Q.X.; Zeng, C.L.; Liu, H.P. Identification of an anti-lipopolysacchride factor possessing both antiviral and antibacterial activity from the red claw crayfish cherax quadricarinatus. Fish Shellfish Immunol. 2016, 57, 213-221. [CrossRef]

44. Hernandez-Aponte, C.A.; Silva-Sanchez, J.; Quintero-Hernandez, V.; Rodriguez-Romero, A.; Balderas, C.; Possani, L.D.; Gurrola, G.B. Vejovine, a new antibiotic from the scorpion venom of vaejovis mexicanus. Toxicon 2011, 57, 84-92. [CrossRef] [PubMed]

45. Bruniera, F.R.; Ferreira, F.M.; Saviolli, L.R.M.; Bacci, M.R.; Feder, D.; Pedreira, M.; Peterlini, M.A.; Azzalis, L.A.; Junqueira, V.B.; Fonseca, F.L.A. The use of vancomycin with its therapeutic and adverse effects: A review. Eur. Rev. Med. Pharm. Sci. 2015, 19, 694-700.

46. Eirich, J.; Orth, R.; Sieber, S.A. Unraveling the protein targets of vancomycin in living S. aureus and E. faecalis cells. J. Am. Chem. Soc. 2011, 133, 12144-12153. [CrossRef] [PubMed]

47. Tripathi, A.; Schofield, M.M.; Chlipala, G.E.; Schultz, P.J.; Yim, I.; Newmister, S.A.; Nusca, T.D.; Scaglione, J.B.; Hanna, P.C.; Tamayo-Castillo, G.; et al. Baulamycins a and b, broad-spectrum antibiotics identified as inhibitors of siderophore biosynthesis in Staphylococcus aureus and Bacillus anthracis. J. Am. Chem. Soc. 2014, 136, 1579-1586. [CrossRef] [PubMed]

48. Feng, Z.; Chakraborty, D.; Dewell, S.B.; Reddy, B.V.; Brady, S.F. Environmental DNA-encoded antibiotics fasamycins a and b inhibit fabf in type ii fatty acid biosynthesis. J. Am. Chem. Soc. 2012, 134, 2981-2987. [CrossRef]

49. Maffioli, S.I.; Fabbretti, A.; Brandi, L.; Savelsbergh, A.; Monciardini, P.; Abbondi, M.; Rossi, R.; Donadio, S.; Gualerzi, C.O. Orthoformimycin, a selective inhibitor of bacterial translation elongation from streptomyces containing an unusual orthoformate. ACS Chem. Biol. 2013, 8, 1939-1946. [CrossRef]

50. Phillips, J.W.; Goetz, M.A.; Smith, S.K.; Zink, D.L.; Polishook, J.; Onishi, R.; Salowe, S.; Wiltsie, J.; Allocco, J.; Sigmund, J.; et al. Discovery of kibdelomycin, a potent new class of bacterial type ii topoisomerase inhibitor by chemical-genetic profiling in Staphylococcus aureus. Chem. Biol. 2011, 18, 955-965. [CrossRef]

51. Singh, S.B. Discovery and development of kibdelomycin, a new class of broad-spectrum antibiotics targeting the clinically proven bacterial type ii topoisomerase. Bioorg. Med. Chem. 2016, 24, 6291-6297. [CrossRef]

52. Wright, G.D. Back to the future: A new 'old' lead for tuberculosis. EMBO Mol. Med. 2012, 4, 1029-1031. [CrossRef]

53. Xiao, Y.; Gerth, K.; Muller, R.; Wall, D. Myxobacterium-produced antibiotic ta (myxovirescin) inhibits type ii signal peptidase. Antimicrob. Agents Chemother. 2012, 56, 2014-2021. [CrossRef]

54. Nonejuie, P.; Burkart, M.; Pogliano, K.; Pogliano, J. Bacterial cytological profiling rapidly identifies the cellular pathways targeted by antibacterial molecules. Proc. Natl. Acad. Sci. USA 2013, 110, 16169-16174. [CrossRef] [PubMed]

55. Ling, L.L.; Schneider, T.; Peoples, A.J.; Spoering, A.L.; Engels, I.; Conlon, B.P.; Mueller, A.; Schaberle, T.F.; Hughes, D.E.; Epstein, S.; et al. A new antibiotic kills pathogens without detectable resistance. Nature 2015, 517, 455-459. [CrossRef] [PubMed]

56. Therien, A.G.; Huber, J.L.; Wilson, K.E.; Beaulieu, P.; Caron, A.; Claveau, D.; Deschamps, K.; Donald, R.G.; Galgoci, A.M.; Gallant, M.; et al. Broadening the spectrum of beta-lactam antibiotics through inhibition of signal peptidase type i. Antimicrob. Agents Chemother. 2012, 56, 4662-4670. [CrossRef] [PubMed] 
57. Navarro, G.; Cheng, A.T.; Peach, K.C.; Bray, W.M.; Bernan, V.S.; Yildiz, F.H.; Linington, R.G. Image-based 384-well high-throughput screening method for the discovery of skyllamycins a to $\mathrm{c}$ as biofilm inhibitors and inducers of biofilm detachment in pseudomonas aeruginosa. Antimicrob. Agents Chemother. 2014, 58, 1092-1099. [CrossRef]

58. Hawksworth, D.L.; Lücking, R. Fungal diversity revisited: 2.2 to 3.8 million species. Microbiol. Spectr. 2017, 5, 79-95.

59. King, A.M.; Reid-Yu, S.A.; Wang, W.; King, D.T.; De Pascale, G.; Strynadka, N.C.; Walsh, T.R.; Coombes, B.K.; Wright, G.D. Aspergillomarasmine a overcomes metallo-beta-lactamase antibiotic resistance. Nature 2014, 510, 503-506. [CrossRef]

60. Ymele-Leki, P.; Cao, S.; Sharp, J.; Lambert, K.G.; McAdam, A.J.; Husson, R.N.; Tamayo, G.; Clardy, J.; Watnick, P.I. A high-throughput screen identifies a new natural product with broad-spectrum antibacterial activity. PLoS ONE 2012, 7, e31307. [CrossRef]

61. Karaman, M.; Jovin, E.; Malbasa, R.; Matavuly, M.; Popovic, M. Medicinal and edible lignicolous fungi as natural sources of antioxidative and antibacterial agents. Phytother. Res. 2010, 24, 1473-1481. [CrossRef]

62. Wu, B.; Wiese, J.; Labes, A.; Kramer, A.; Schmaljohann, R.; Imhoff, J.F. Lindgomycin, an unusual antibiotic polyketide from a marine fungus of the lindgomycetaceae. Mar. Drugs 2015, 13, 4617-4632. [CrossRef]

63. Wei, M.Y.; Li, D.; Shao, C.L.; Deng, D.S.; Wang, C.Y. (+/-)-pestalachloride d, an antibacterial racemate of chlorinated benzophenone derivative from a soft coral-derived fungus Pestalotiopsis sp. Mar. Drugs 2013, 11, 1050-1060. [CrossRef]

64. Pruksakorn, P.; Arai, M.; Kotoku, N.; Vilcheze, C.; Baughn, A.D.; Moodley, P.; Jacobs, W.R., Jr.; Kobayashi, M. Trichoderins, novel aminolipopeptides from a marine sponge-derived Trichoderma sp., are active against dormant mycobacteria. Bioorg. Med. Chem. Lett. 2010, 20, 3658-3663. [CrossRef] [PubMed]

65. Chandra, H.; Bishnoi, P.; Yadav, A.; Patni, B.; Mishra, A.P.; Nautiyal, A.R. Antimicrobial resistance and the alternative resources with special emphasis on plant-based antimicrobials-A review. Plants 2017, 6, 16. [CrossRef] [PubMed]

66. Quideau, S.; Deffieux, D.; Douat-Casassus, C.; Pouysegu, L. Plant polyphenols: Chemical properties, biological activities, and synthesis. Angew. Chem. Int. Ed. Engl. 2011, 50, 586-621. [CrossRef] [PubMed]

67. Harvey, A.L.; Edrada-Abel, R.; Quinn, R.J. The re-emergence of natural products for drug discovery in the genomics era. Nat. Rev. Drug Discov. 2015, 14, 111-129. [CrossRef]

68. Radulovic, N.S.B.; Blagojevic, P.D.; Stojanovic-Radic, Z.Z.; Stojanovic, N.M. Antimicrobial plant metabolites: Structural diversity and mechanism of action. Curr. Med. Chem. 2013, 20, 932-952.

69. Coban, I.; Toplan, G.G.; Ozbek, B.; Gurer, C.U.; Sariyar, G. Variation of alkaloid contents and antimicrobial activities of papaver rhoeas 1 . Growing in turkey and northern cyprus. Pharm. Biol. 2017, 55, 1894-1898. [CrossRef]

70. Nugraha, A.S.; Damayanti, Y.D.; Wangchuk, P.; Keller, P.A. Anti-infective and anti-cancer properties of the annona species: Their ethnomedicinal uses, alkaloid diversity, and pharmacological activities. Molecules 2019, 24, 4419. [CrossRef]

71. Tian, J.; Ban, X.; Zeng, H.; He, J.; Huang, B.; Wang, Y. Chemical composition and antifungal activity of essential oil from Cicuta virosa L. Var. Latisecta celak. Int. J. Food Microbiol. 2011, 145, 464-470. [CrossRef]

72. Tariq, S.; Wani, S.; Rasool, W.; Shafi, K.; Bhat, M.A.; Prabhakar, A.; Shalla, A.H.; Rather, M.A. A comprehensive review of the antibacterial, antifungal and antiviral potential of Essential oils and their chemical constituents against drug-resistant microbial pathogens. Microb. Pathog. 2019, 134, 103580. [CrossRef]

73. Yang, Y.; Zhang, T. Antimicrobial activities of tea polyphenol on phytopathogens: A review. Molecules 2019, 24, 816. [CrossRef]

74. Bouarab Chibane, L.; Degraeve, P.; Ferhout, H.; Bouajila, J.; Oulahal, N. Plant antimicrobial polyphenols as potential natural food preservatives. J. Sci. Food Agric. 2019, 99, 1457-1474. [CrossRef] [PubMed]

75. Bostanghadiri, N.; Pormohammad, A.; Chirani, A.S.; Pouriran, R.; Erfanimanesh, S.; Hashemi, A. Comprehensive review on the antimicrobial potency of the plant polyphenol resveratrol. Biomed. Pharm. 2017, 95, 1588-1595. [CrossRef] [PubMed]

76. Alvarez-Martinez, F.J.; Barrajon-Catalan, E.; Encinar, J.A.; Rodriguez-Diaz, J.C.; Micol, V. Antimicrobial capacity of plant polyphenols against gram-positive bacteria: A comprehensive review. Curr. Med. Chem. 2018, 27, 2576-2606. [CrossRef] [PubMed] 
77. Su, Y.; Ma, L.; Wen, Y.; Wang, H.; Zhang, S. Studies of the in vitro antibacterial activities of several polyphenols against clinical isolates of methicillin-resistant Staphylococcus aureus. Molecules 2014, 19, 12630-12639. [CrossRef]

78. Mokhtar, M.; Ginestra, G.; Youcefi, F.; Filocamo, A.; Bisignano, C.; Riazi, A. Antimicrobial activity of selected polyphenols and capsaicinoids identified in pepper (Capsicum annuиm L.) and their possible mode of interactio. Curr. Microbiol. 2017, 74, 1253-1260. [CrossRef]

79. Caselli, A.; Cirri, P.; Santi, A.; Paoli, P. Morin: A promising natural drug. Curr. Med. Chem. 2016, $23,774-791$. [CrossRef]

80. Tomas-Menor, L.; Barrajon-Catalan, E.; Segura-Carretero, A.; Marti, N.; Saura, D.; Menendez, J.A.; Joven, J.; Micol, V. The promiscuous and synergic molecular interaction of polyphenols in bactericidal activity: An opportunity to improve the performance of antibiotics? Phytother. Res. 2015, 29, 466-473. [CrossRef]

81. Bai, L.; Takagi, S.; Ando, T.; Yoneyama, H.; Ito, K.; Mizugai, H.; Isogai, E. Antimicrobial activity of tea catechin against canine oral bacteria and the functional mechanisms. J. Vet. Med. Sci. 2016, 78, 1439-1445. [CrossRef]

82. Cushnie, T.P.; Hamilton, V.E.; Lamb, A.J. Assessment of the antibacterial activity of selected flavonoids and consideration of discrepancies between previous reports. Microbiol. Res. 2003, 158, 281-289. [CrossRef]

83. Cushnie, T.P.; Lamb, A.J. Antimicrobial activity of flavonoids. Int. J. Antimicrob. Agents 2005, 26, 343-356. [CrossRef]

84. Xu, Y.; Shi, C.; Wu, Q.; Zheng, Z.; Liu, P.; Li, G.; Peng, X.; Xia, X. Antimicrobial activity of punicalagin against Staphylococcus aureus and its effect on biofilm formation. Foodborne Pathog. Dis. 2017, 14, 282-287. [CrossRef] [PubMed]

85. Daglia, M. Polyphenols as antimicrobial agents. Curr. Opin. Biotechnol. 2012, 23, 174-181. [CrossRef] [PubMed]

86. Bernal, P.; Lemaire, S.; Pinho, M.G.; Mobashery, S.; Hinds, J.; Taylor, P.W. Insertion of epicatechin gallate into the cytoplasmic membrane of methicillin-resistant Staphylococcus aureus disrupts penicillin-binding protein (pbp) 2a-mediated beta-lactam resistance by delocalizing pbp2. J. Biol. Chem. 2010, 285, 24055-24065. [CrossRef] [PubMed]

87. Miklasinska-Majdanik, M.; Kepa, M.; Wojtyczka, R.D.; Idzik, D.; Wasik, T.J. Phenolic compounds diminish antibiotic resistance of Staphylococcus aureus clinical strains. Int. J. Environ. Res. Public Health 2018, 15, 2321. [CrossRef] [PubMed]

88. Qin, R.; Xiao, K.; Li, B.; Jiang, W.; Peng, W.; Zheng, J.; Zhou, H. The combination of catechin and epicatechin callate from fructus crataegi potentiates beta-lactam antibiotics against methicillin-resistant staphylococcus aureus (mrsa) in vitro and in vivo. Int. J. Mol. Sci. 2013, 14, 1802-1821. [CrossRef] [PubMed]

89. Betts, J.W.; Sharili, A.S.; Phee, L.M.; Wareham, D.W. In vitro activity of epigallocatechin gallate and quercetin alone and in combination versus clinical isolates of methicillin-resistant Staphylococcus aureus. J. Nat. Prod. 2015, 78, 2145-2148. [CrossRef]

90. Zwingelstein, M.; Draye, M.; Besombes, J.L.; Piot, C.; Chatel, G. Viticultural wood waste as a source of polyphenols of interest: Opportunities and perspectives through conventional and emerging extraction methods. Waste Manag. 2020, 102, 782-794. [CrossRef]

91. Tomas-Menor, L.; Morales-Soto, A.; Barrajon-Catalan, E.; Roldan-Segura, C.; Segura-Carretero, A.; Micol, V. Correlation between the antibacterial activity and the composition of extracts derived from various spanish cistus species. Food Chem. Toxicol. 2013, 55, 313-322. [CrossRef]

92. Dubey, D.; Padhy, R.N. Antibacterial activity of Lantana camara L. Against multidrug resistant pathogens from icu patients of a teaching hospital. J. Herb. Med. 2013, 3, 65-75. [CrossRef]

93. Dubey, D.; Sahu, M.C.; Rath, S.; Paty, B.P.; Debata, N.K.; Padhy, R.N. Antimicrobial activity of medicinal plants used by aborigines of kalahandi, orissa, india against multidrug resistant bacteria. Asian Pac. J. Trop. Biomed. 2012, 2, S846-S854. [CrossRef]

94. Sahu, M.C.; Padhy, R.N. In vitro antibacterial potency of Butea monosperma Lam. Against 12 clinically isolated multidrug resistant bacteria. Asian Pac. J. Trop. Dis. 2013, 3, 217-226. [CrossRef]

95. Mak, S.; Nodwell, J.R. Actinorhodin is a redox-active antibiotic with a complex mode of action against gram-positive cells. Mol. Microbiol. 2017, 106, 597-613. [CrossRef] [PubMed]

96. Lin, Z.; Xu, X.; Zhao, S.; Yang, X.; Guo, J.; Zhang, Q.; Jing, C.; Chen, S.; He, Y. Total synthesis and antimicrobial evaluation of natural albomycins against clinical pathogens. Nat. Commun. 2018, 9, 3445. [CrossRef] [PubMed] 
97. Pramanik, A.; Stroeher, U.H.; Krejci, J.; Standish, A.J.; Bohn, E.; Paton, J.C.; Autenrieth, I.B.; Braun, V. Albomycin is an effective antibiotic, as exemplified with Yersinia enterocolitica and Streptococcus pneumoniae. Int. J. Med. Microbiol. 2007, 297, 459-469. [CrossRef]

98. Singh, M.; Chang, J.; Coffman, L.; Kim, S.J. Solid-state nmr characterization of amphomycin effects on peptidoglycan and wall teichoic acid biosyntheses in Staphylococcus aureus. Sci. Rep. 2016, 6, 31757. [CrossRef]

99. Kang, A.D.; Smith, K.P.; Eliopoulos, G.M.; Berg, A.H.; McCoy, C.; Kirby, J.E. Invitro apramycin activity against multidrug-resistant Acinetobacter baumannii and Pseudomonas aeruginosa. Diagn. Microbiol. Infect. Dis. 2017, 88, 188-191. [CrossRef]

100. Liu, J.; Smith, P.A.; Steed, D.B.; Romesberg, F. Efforts toward broadening the spectrum of arylomycin antibiotic activity. Bioorg. Med. Chem. Lett. 2013, 23, 5654-5659. [CrossRef]

101. Zhong, J.; Lu, Z.; Dai, J.; He, W. Identification of two regulatory genes involved in carbomycin biosynthesis in streptomyces thermotolerans. Arch. Microbiol. 2017, 199, 1023-1033. [CrossRef]

102. Zheng, Z.; Tharmalingam, N.; Liu, Q.; Jayamani, E.; Kim, W.; Fuchs, B.B.; Zhang, R.; Vilcinskas, A.; Mylonakis, E. Synergistic efficacy of aedes aegypti antimicrobial peptide cecropin a2 and tetracycline against Pseudomonas aeruginosa. Antimicrob. Agents 2017, 61, e00617-e00686. [CrossRef]

103. Gustaferro, C.A.; Steckelberg, J.M. Cephalosporin antimicrobial agents and related compounds. Mayo Clin. Proc. 1991, 66, 1064-1073. [CrossRef]

104. Brites, L.M.; Oliveira, L.M.; Barboza, M. Kinetic study on cephamycin c degradation. Appl. Biochem. Biotechnol. 2013, 171, 2121-2128. [CrossRef] [PubMed]

105. Schwarz, S.; Kehrenberg, C.; Doublet, B.; Cloeckaert, A. Molecular basis of bacterial resistance to chloramphenicol and florfenicol. FEMS Microbiol. Rev. 2004, 28, 519-542. [CrossRef] [PubMed]

106. Allen, N.E.; Nicas, T.I. Mechanism of action of oritavancin and related glycopeptide antibiotics. FEMS Microbiol. Rev. 2003, 26, 511-532. [CrossRef] [PubMed]

107. Hakami, A.Y.; Sari, Y. Beta-lactamase inhibitor, clavulanic acid, attenuates ethanol intake and increases glial glutamate transporters expression in alcohol preferring rats. Neurosci. Lett. 2017, 657, 140-145. [CrossRef]

108. Eustáquio, A.S.; Gust, B.; Luft, T.; Li, S.-M.; Chater, K.F.; Heide, L. Clorobiocin biosynthesis in streptomyces. Chem. Biol. 2003, 10, 279-288. [CrossRef]

109. Samuels, D.S.; Garon, C.F. Coumermycin a1 inhibits growth and induces relaxation of supercoiled plasmids in borrelia burgdorferi, the lyme disease agent. Antimicrob. Agents Chemother. 1993, 37, 46-50. [CrossRef]

110. Fedorko, J.; Katz, S.; Allnoch, H. In vitro activity of coumermycin a. Appl. Microbiol. 1969, 18, 869-873. [CrossRef]

111. Cercenado, E. Espectro antimicrobiano de dalbavancina. Mecanismo de acción y actividad in vitro frente a microorganismos gram positivos. Enferm. Infecc. Y Microbiol. Clín. 2017, 35, 9-14. [CrossRef]

112. Heidary, M.; Khosravi, A.D.; Khoshnood, S.; Nasiri, M.J.; Soleimani, S.; Goudarzi, M. Daptomycin. J. Antimicrob. Chemother. 2018, 73, 1-11. [CrossRef]

113. Chu, C.; Deng, J.; Man, Y.; Qu, Y. Green tea extracts epigallocatechin-3-gallate for different treatments. BioMed Res. Int. 2017, 2017, 5615647. [CrossRef]

114. Li, Z.; He, M.; Dong, X.; Lin, H.; Ge, H.; Shen, S.; Li, J.; Ye, R.D.; Chen, D. New erythromycin derivatives enhance beta-lactam antibiotics against methicillin-resistant Staphylococcus aureus. Lett. Appl. Microbiol. 2015, 60, 352-358. [CrossRef] [PubMed]

115. Falagas, M.E.; Vouloumanou, E.K.; Samonis, G.; Vardakas, K.Z. Fosfomycin. Clin. Microbiol. Rev. 2016, 29, 321-347. [CrossRef] [PubMed]

116. Curbete, M.M.; Salgado, H.R. A critical review of the properties of fusidic acid and analytical methods for its determination. Crit. Rev. Anal. Chem. 2016, 46, 352-360. [CrossRef] [PubMed]

117. Wargo, K.A.; Edwards, J.D. Aminoglycoside-induced nephrotoxicity. J. Pharm. Pr. 2014, 27, 573-577. [CrossRef] [PubMed]

118. Wenzel, M.; Rautenbach, M.; Vosloo, J.A.; Siersma, T.; Aisenbrey, C.H.; Zaitseva, E.; Laubscher, W.E.; Rensburg, W.; Behrends, J.C.; Bechinger, B.; et al. The multifaceted antibacterial mechanisms of the pioneering peptide antibiotics tyrocidine and gramicidin s. mBio 2018, 9, e00802-18. [CrossRef]

119. Wei, L.; Gao, J.; Zhang, S.; Wu, S.; Xie, Z.; Ling, G.; Kuang, Y.Q.; Yang, Y.; Yu, H.; Wang, Y. Identification and characterization of the first cathelicidin from sea snakes with potent antimicrobial and anti-inflammatory activity and special mechanism. J. Biol. Chem. 2015, 290, 16633-16652. [CrossRef] 
120. Guerrero, M.C.; Modolell, J. Hygromycin a, a novel inhibitor of ribosomal peptidyltransferase. Eur. J. Biochem. 1980, 107, 409-414. [CrossRef]

121. Arsic, B.; Barber, J.; Cikos, A.; Mladenovic, M.; Stankovic, N.; Novak, P. 16-membered macrolide antibiotics: A review. Int. J. Antimicrob. Agents 2018, 51, 283-298. [CrossRef]

122. Hoerr, V.; Duggan, G.E.; Zbytnuik, L.; Poon, K.K.; Grosse, C.; Neugebauer, U.; Methling, K.; Loffler, B.; Vogel, H.J. Characterization and prediction of the mechanism of action of antibiotics through nmr metabolomics. BMC Microbiol. 2016, 16, 82. [CrossRef]

123. Beretta, G. Novel producer of the antibiotic kirromycin belonging to the genus actinoplanes. J. Antibiot. 1993, 46, 1175-1177. [CrossRef]

124. Wolf, H.; Chinali, G.; Parmeggiani, A. Kirromycin, an inhibitor of protein biosynthesis that acts on elongation factor tu. Proc. Natl. Acad. Sci. USA 1974, 71, 4910-4914. [CrossRef] [PubMed]

125. Spizek, J.; Rezanka, T. Lincomycin, clindamycin and their applications. Appl. Microbiol. Biotechnol. 2004, 64, 455-464. [CrossRef] [PubMed]

126. Kurabachew, M.; Lu, S.H.; Krastel, P.; Schmitt, E.K.; Suresh, B.L.; Goh, A.; Knox, J.E.; Ma, N.L.; Jiricek, J.; Beer, D.; et al. Lipiarmycin targets rna polymerase and has good activity against multidrug-resistant strains of mycobacterium tuberculosis. J. Antimicrob. Chemother. 2008, 62, 713-719. [CrossRef] [PubMed]

127. Rebets, Y.; Lupoli, T.; Qiao, Y.; Schirner, K.; Villet, R.; Hooper, D.; Kahne, D.; Walker, S. Moenomycin resistance mutations in Staphylococcus aureus reduce peptidoglycan chain length and cause aberrant cell division. ACS Chem. Biol. 2014, 9, 459-467. [CrossRef]

128. Dai, C.; Ma, Y.; Zhao, Z.; Zhao, R.; Wang, Q.; Wu, Y.; Cao, Z.; Li, W. Mucroporin, the first cationic host defense peptide from the venom of Lychas mucronatus. Antimicrob. Agents Chemother. 2008, 52, 3967-3972. [CrossRef]

129. Blanchard, C.; Brooks, L.; Beckley, A.; Colquhoun, J.; Dewhurst, S.; Dunman, P.M. Neomycin sulfate improves the antimicrobial activity of mupirocin-based antibacterial ointments. Antimicrob. Agents Chemother. 2016, 60, 862-872. [CrossRef]

130. Leal, J.F.; Henriques, I.S.; Correia, A.; Santos, E.B.H.; Esteves, V.I. Antibacterial activity of oxytetracycline photoproducts in marine aquaculture's water. Environ. Pollut. 2017, 220, 644-649. [CrossRef]

131. Wright, A.J. The penicillins. Mayo Clin. Proc. 1999, 74, 290-307. [CrossRef]

132. Paukner, S.; Riedl, R. Pleuromutilins: Potent drugs for resistant bugs-mode of action and resistance. Cold Spring Harb. Perspect. Med. 2017, 7, a027110. [CrossRef]

133. Trimble, M.J.; Mlynarcik, P.; Kolar, M.; Hancock, R.E. Polymyxin: Alternative mechanisms of action and resistance. Cold Spring Harb. Perspect. Med. 2016, 6, a025288. [CrossRef]

134. Cooper, E.C.; Curtis, N.; Cranswick, N.; Gwee, A. Pristinamycin: Old drug, new tricks? J. Antimicrob. Chemother. 2014, 69, 2319-2325. [CrossRef] [PubMed]

135. Wang, S.; Yao, J.; Zhou, B.; Yang, J.; Chaudry, M.T.; Wang, M.; Xiao, F.; Li, Y.; Yin, W. Bacteriostatic effect of quercetin as an antibiotic alternative in vivo and its antibacterial mechanism in vitro. J. Food. Prot. 2018, 81, 68-78. [CrossRef] [PubMed]

136. de la Cruz, M.; Gonzalez, I.; Parish, C.A.; Onishi, R.; Tormo, J.R.; Martin, J.; Pelaez, F.; Zink, D.; El Aouad, N.; Reyes, F.; et al. Production of ramoplanin and ramoplanin analogs by actinomycetes. Front. Microbiol. 2017, 8, 343. [CrossRef] [PubMed]

137. Floss, H.G.; Yu, T.W. Rifamycins mode of action, resistance, and biosynthesis. Chem. Rev. 2005, 105, 621-632. [CrossRef]

138. Nahoum, V.; Spector, S.; Loll, P.J. Structure of ristocetin a in complex with a bacterial cell-wall mimetic. Acta Cryst. D Biol. Cryst. 2009, 65, 832-838. [CrossRef]

139. Sweeney, P.; Murphy, C.D.; Caffrey, P. Exploiting the genome sequence of streptomyces nodosus for enhanced antibiotic production. Appl. Microbiol. Biotechnol. 2016, 100, 1285-1295. [CrossRef]

140. Yang, L.L.; Zhan, M.Y.; Zhuo, Y.L.; Pan, Y.M.; Xu, Y.; Zhou, X.H.; Yang, P.J.; Liu, H.L.; Liang, Z.H.; Huang, X.D.; et al. Antimicrobial activities of a proline-rich proprotein from Spodoptera litura. Dev. Comp. Immunol. 2018, 87, 137-146. [CrossRef]

141. Holloway, W.J. Spectinomyein. Med. Clin. N. Am. 1982, 66, 169-173. [CrossRef]

142. Rubinstein, E.; Keller, N. Spiramycin renaissance. J. Antimicrob. Chemother. 1998, 42, 572-576. [CrossRef]

143. Webb, H.E.; Angulo, F.J.; Granier, S.A.; Scott, H.M.; Loneragan, G.H. Illustrative examples of probable transfer of resistance determinants from food animals to humans: Streptothricins, glycopeptides, and colistin. F1000Research 2017, 6, 1805. [CrossRef] 
144. Ramos-Martin, V.; Johnson, A.; McEntee, L.; Farrington, N.; Padmore, K.; Cojutti, P.; Pea, F.; Neely, M.N.; Hope, W.W. Pharmacodynamics of teicoplanin against mrsa. J. Antimicrob. Chemother. 2017, 72, 3382-3389. [CrossRef] [PubMed]

145. Nguyen, F.; Starosta, A.L.; Arenz, S.; Sohmen, D.; Dönhöfer, A.; Wilson, D.N. Tetracycline antibiotics and resistance mechanisms. Biol. Chem. 2014, 395, 559-575. [CrossRef] [PubMed]

146. Papp-Wallace, K.M.; Endimiani, A.; Taracila, M.A.; Bonomo, R.A. Carbapenems: Past, present, and future. Antimicrob. Agents Chemother. 2011, 55, 4943-4960. [CrossRef] [PubMed]

147. Nicolaou, K.C. How thiostrepton was made in the laboratory. Angew. Chem. Int. Ed. Engl. 2012, 51, 12414-12436. [CrossRef] [PubMed]

148. Bothra, M.; Lodha, R.; Kabra, S.K. Tobramycin for the treatment of bacterial pneumonia in children. Expert Opin. Pharm. 2012, 13, 565-571. [CrossRef]

149. Yamamoto, K.; Ichikawa, S. Tunicamycin: Chemical synthesis and biosynthesis. J. Antibiot. 2019, 72, 924-933. [CrossRef]

150. Huang, L.; Zhang, H.; Li, M.; Ahmad, I.; Wang, Y.; Yuan, Z. Pharmacokinetic-pharmacodynamic modeling of tylosin against Streptococcus suis in pigs. BMC Vet. Res. 2018, 14, 319. [CrossRef]

151. Holm, M.; Borg, A.; Ehrenberg, M.; Sanyal, S. Molecular mechanism of viomycin inhibition of peptide elongation in bacteria. Proc. Natl. Acad. Sci. USA 2016, 113, 978-983. [CrossRef]

152. Bischoff, K.M.; Zhang, Y.; Rich, J.O. Fate of virginiamycin through the fuel ethanol production process. World J. Microbiol. Biotechnol. 2016, 32, 76. [CrossRef]

153. Lee, T.H.; Hall, K.N.; Aguilar, M.I. Antimicrobial peptide structure and mechanism of action: A focus on the role of membrane structure. Curr. Top. Med. Chem. 2016, 16, 25-39. [CrossRef]

154. Bhattacharya, D.; Ghosh, D.; Bhattacharya, S.; Sarkar, S.; Karmakar, P.; Koley, H.; Gachhui, R. Antibacterial activity of polyphenolic fraction of kombucha against Vibrio cholerae: Targeting cell membrane. Lett. Appl. Microbiol. 2018, 66, 145-152. [CrossRef]

155. Kakarla, P.; Floyd, J.; Mukherjee, M.; Devireddy, A.R.; Inupakutika, M.A.; Ranweera, I.; Kc, R.; Shrestha, U.; Cheeti, U.R.; Willmon, T.M.; et al. Inhibition of the multidrug efflux pump lmrs from Staphylococcus aureus by cumin spice Cuminum cyminum. Arch. Microbiol. 2017, 199, 465-474. [CrossRef] [PubMed]

156. Skariyachan, S.; Sridhar, V.S.; Packirisamy, S.; Kumargowda, S.T.; Challapilli, S.B. Recent perspectives on the molecular basis of biofilm formation by Pseudomonas aeruginosa and approaches for treatment and biofilm dispersal. Folia Microbiol. 2018, 63, 413-432. [CrossRef] [PubMed]

157. Inui, T.; Wang, Y.; Deng, S.; Smith, D.C.; Franzblau, S.G.; Pauli, G.F. Counter-current chromatography based analysis of synergy in an anti-tuberculosis ethnobotanical. J. Chromatogr. A 2007, 1151, 211-215. [CrossRef]

158. Cheesman, J.M.; Ilanko, A.; Blonk, B.; Cock, I.E. Developing new antimicrobial therapies: Are synergistic combinations of plant extracts/compounds with conventional antibiotics the solution? Pharm. Rev. 2017, 11, 57-72.

159. Chan, B.C.; Ip, M.; Lau, C.B.; Lui, S.L.; Jolivalt, C.; Ganem-Elbaz, C.; Litaudon, M.; Reiner, N.E.; Gong, H.; See, R.H.; et al. Synergistic effects of baicalein with ciprofloxacin against nora over-expressed methicillin-resistant Staphylococcus aureus (mrsa) and inhibition of mrsa pyruvate kinase. J. Ethnopharmacol. 2011, 137, 767-773. [CrossRef]

160. Kalia, N.P.; Mahajan, P.; Mehra, R.; Nargotra, A.; Sharma, J.P.; Koul, S.; Khan, I.A. Capsaicin, a novel inhibitor of the nora efflux pump, reduces the intracellular invasion of Staphylococcus aureus. J. Antimicrob. Chemother. 2012, 67, 2401-2408. [CrossRef]

161. Ponnusamy, K.; Ramasamy, M.; Savarimuthu, I.; Paulraj, M.G. Indirubin potentiates ciprofloxacin activity in the nora efflux pump of Staphylococcus aureus. Scand. J. Infect. Dis. 2010, 42, 500-505. [CrossRef]

162. Holler, J.G.; Christensen, S.B.; Slotved, H.C.; Rasmussen, H.B.; Guzman, A.; Olsen, C.E.; Petersen, B.; Molgaard, P. Novel inhibitory activity of the Staphylococcus aureus nora efflux pump by a kaempferol rhamnoside isolated from Persea lingue nees. J. Antimicrob. Chemother. 2012, 67, 1138-1144. [CrossRef]

163. Shiu, W.K.; Malkinson, J.P.; Rahman, M.M.; Curry, J.; Stapleton, P.; Gunaratnam, M.; Neidle, S.; Mushtaq, S.; Warner, M.; Livermore, D.M.; et al. A new plant-derived antibacterial is an inhibitor of efflux pumps in Staphylococcus aureus. Int. J. Antimicrob. Agents 2013, 42, 513-518. [CrossRef]

164. Bame, J.R.; Graf, T.N.; Junio, H.A.; Bussey, R.O., III; Jarmusch, S.A.; El-Elimat, T.; Falkinham, J.O., III; Oberlies, N.H.; Cech, R.A.; Cech, N.B. Sarothrin from Alkanna orientalis is an antimicrobial agent and efflux pump inhibitor. Planta Med. 2013, 79, 327-329. [CrossRef] [PubMed] 
165. Roy, S.K.; Pahwa, S.; Nandanwar, H.; Jachak, S.M. Phenylpropanoids of Alpinia galanga as efflux pump inhibitors in Mycobacterium smegmatis mc(2) 155. Fitoterapia 2012, 83, 1248-1255. [CrossRef] [PubMed]

166. Dwivedi, G.R.; Tyagi, R.; Sanchita; Tripathi, S.; Pati, S.; Srivastava, S.K.; Darokar, M.P.; Sharma, A. Antibiotics potentiating potential of catharanthine against superbug Pseudomonas aeruginosa. J. Biomol. Struct. Dyn. 2018, 36, 4270-4284. [CrossRef] [PubMed]

167. Maisuria, V.B.; Hosseinidoust, Z.; Tufenkji, N. Polyphenolic extract from maple syrup potentiates antibiotic susceptibility and reduces biofilm formation of pathogenic bacteria. Appl. Environ. Microbiol. 2015, 81, 3782-3792. [CrossRef]

168. Bag, A.; Chattopadhyay, R.R. Efflux-pump inhibitory activity of a gallotannin from Terminalia chebula fruit against multidrug-resistant uropathogenic Escherichia coli. Nat. Prod. Res. 2014, 28, 1280-1283. [CrossRef]

169. Dwivedi, G.R.; Maurya, A.; Yadav, D.K.; Khan, F.; Darokar, M.P.; Srivastava, S.K. Drug resistance reversal potential of ursolic acid derivatives against nalidixic acid- and multidrug-resistant Escherichia coli. Chem. Biol. Drug Des. 2015, 86, 272-283. [CrossRef]

170. Maurya, A.; Dwivedi, G.R.; Darokar, M.P.; Srivastava, S.K. Antibacterial and synergy of clavine alkaloid lysergol and its derivatives against nalidixic acid-resistant Escherichia coli. Chem. Biol. Drug Des. 2013, 81, 484-490. [CrossRef]

171. Aghayan, S.S.; Mogadam, H.K.; Fazli, M.; Darban-Sarokhalil, D.; Khoramrooz, S.S.; Jabalameli, F.; Yaslianifard, S.; Mirzaii, M. The effects of berberine and palmatine on efflux pumps inhibition with different gene patterns in Pseudomonas aeruginosa isolated from burn infections. Avicenna J. Med. Biotechnol. 2017, 9, 2-7.

172. Adwan, G.; Abu-Shanab, B.; Adwan, K. Antibacterial activities of some plant extracts alone and in combination with different antimicrobials against multidrug-resistant Pseudomonas aeruginosa strains. Asian Pac. J. Trop. Biomed. 2010, 3, 266-269. [CrossRef]

173. Shriram, V.; Khare, T.; Bhagwat, R.; Shukla, R.; Kumar, V. Inhibiting bacterial drug efflux pumps via phyto-therapeutics to combat threatening antimicrobial resistance. Front. Microbiol. 2018, 9, 2990. [CrossRef]

174. Sudano Roccaro, A.; Blanco, A.R.; Giuliano, F.; Rusciano, D.; Enea, V. Epigallocatechin-gallate enhances the activity of tetracycline in staphylococci by inhibiting its efflux from bacterial cells. Antimicrob. Agents Chemother. 2004, 48, 1968-1973. [CrossRef] [PubMed]

175. Sousa, V.; Luis, A.; Oleastro, M.; Domingues, F.; Ferreira, S. Polyphenols as resistance modulators in Arcobacter butzleri. Folia Microbiol. 2019, 64, 547-554. [CrossRef] [PubMed]

176. Fazly Bazzaz, B.S.; Sarabandi, S.; Khameneh, B.; Hosseinzadeh, H. Effect of catechins, green tea extract and methylxanthines in combination with gentamicin against Staphylococcus aureus and Pseudomonas aeruginosa: -combination therapy against resistant bacteria. J. Pharmacopunct. 2016, 19, 312-318. [CrossRef] [PubMed]

177. Palacios, L.; Rosado, H.; Micol, V.; Rosato, A.E.; Bernal, P.; Arroyo, R.; Grounds, H.; Anderson, J.C.; Stabler, R.A.; Taylor, P.W. Staphylococcal phenotypes induced by naturally occurring and synthetic membrane-interactive polyphenolic beta-lactam resistance modifiers. PLoS ONE 2014, 9, e93830. [CrossRef] [PubMed]

178. Stapleton, P.D.; Shah, S.; Anderson, J.C.; Hara, Y.; Hamilton-Miller, J.M.; Taylor, P.W. Modulation of beta-lactam resistance in Staphylococcus aureus by catechins and gallates. Int. J. Antimicrob. Agents 2004, 23, 462-467. [CrossRef]

179. Stapleton, P.D.; Shah, S.; Hara, Y.; Taylor, P.W. Potentiation of catechin gallate-mediated sensitization of Staphylococcus aureus to oxacillin by nongalloylated catechins. Antimicrob. Agents Chemother. 2006, 50, 752-755. [CrossRef]

180. Santiago, C.; Pang, E.L.; Lim, K.H.; Loh, H.S.; Ting, K.N. Inhibition of penicillin-binding protein 2a (pbp2a) in methicillin resistant Staphylococcus aureus (mrsa) by combination of ampicillin and a bioactive fraction from Duabanga grandiflora. BMC Complement. Altern. Med. 2015, 15, 178. [CrossRef]

181. Khan, R.; Islam, B.; Akram, M.; Shakil, S.; Ahmad, A.; Ali, S.M.; Siddiqui, M.; Khan, A.U. Antimicrobial activity of five herbal extracts against multi drug resistant $(\mathrm{mdr})$ strains of bacteria and fungus of clinical origin. Molecules 2009, 14, 586-597. [CrossRef]

182. Chovanova, R.; Mikulasova, M.; Vaverkova, S. In vitro antibacterial and antibiotic resistance modifying effect of bioactive plant extracts on methicillin-resistant Staphylococcus epidermidis. Int. J. Microbiol. 2013, 2013, 760969. [CrossRef] 
183. Hall, C.W.; Mah, T.F. Molecular mechanisms of biofilm-based antibiotic resistance and tolerance in pathogenic bacteria. FEMS Microbiol. Rev. 2017, 41, 276-301. [CrossRef]

184. Rasamiravaka, T.; Labtani, Q.; Duez, P.; El Jaziri, M. The formation of biofilms by Pseudomonas aeruginosa: A review of the natural and synthetic compounds interfering with control mechanisms. BioMed Res. Int. 2015, 2015, 759348. [CrossRef] [PubMed]

185. Alkawash, M.A.; Soothill, J.S.; Schiller, N.L. Alginate lyase enhances antibiotic killing of mucoid Pseudomonas aeruginosa in biofilms. APMIS 2006, 114, 131-138. [CrossRef]

186. Ren, D.; Zuo, R.; Gonzalez Barrios, A.F.; Bedzyk, L.A.; Eldridge, G.R.; Pasmore, M.E.; Wood, T.K. Differential gene expression for investigation of Escherichia coli biofilm inhibition by plant extract ursolic acid. Appl. Environ. Microbiol. 2005, 71, 4022-4034. [CrossRef] [PubMed]

187. Kim, H.S.; Park, H.D. Ginger extract inhibits biofilm formation by Pseudomonas aeruginosa pa14. PLoS ONE 2013, 8, e76106. [CrossRef] [PubMed]

188. Ulrey, R.K.; Barksdale, S.M.; Zhou, W.; van Hoek, M.L. Cranberry proanthocyanidins have anti biofilm properties against Pseudomonas aeruginosa. BMC Complement. Altern. Med. 2014, 14, 1-12. [CrossRef] [PubMed]

189. Carneiro, V.A.; Santos, H.S.; Arruda, F.V.; Bandeira, P.N.; Albuquerque, M.R.; Pereira, M.O.; Henriques, M.; Cavada, B.S.; Teixeira, E.H. Casbane diterpene as a promising natural antimicrobial agent against biofilm-associated infections. Molecules 2010, 16, 190-201. [CrossRef] [PubMed]

190. Skindersoe, M.E.; Ettinger-Epstein, P.; Rasmussen, T.B.; Bjarnsholt, T.; de Nys, R.; Givskov, M. Quorum sensing antagonism from marine organisms. Mar. Biotechnol. 2008, 10, 56-63. [CrossRef]

191. Park, J.; Kaufmann, G.F.; Bowen, J.P.; Arbiser, J.L.; Janda, K.D. Solenopsin a, a venom alkaloid from the fire ant Solenopsis invicta, inhibits quorum-sensing signaling in Pseudomonas aeruginosa. J. Infect. Dis. 2008, 198, 1198-1201. [CrossRef]

192. Vandeputte, O.M.; Kiendrebeogo, M.; Rajaonson, S.; Diallo, B.; Mol, A.; El Jaziri, M.; Baucher, M. Identification of catechin as one of the flavonoids from Combretum albiflorum bark extract that reduces the production of quorum-sensing-controlled virulence factors in Pseudomonas aeruginosa pao1. Appl. Environ. Microbiol. 2010, 76, 243-253. [CrossRef]

193. Vandeputte, O.M.; Kiendrebeogo, M.; Rasamiravaka, T.; Stevigny, C.; Duez, P.; Rajaonson, S.; Diallo, B.; Mol, A.; Baucher, M.; El Jaziri, M. The flavanone naringenin reduces the production of quorum sensing-controlled virulence factors in Pseudomonas aeruginosa pao1. Microbiology 2011, 157, 2120-2132. [CrossRef]

194. Jakobsen, T.H.; van Gennip, M.; Phipps, R.K.; Shanmugham, M.S.; Christensen, L.D.; Alhede, M.; Skindersoe, M.E.; Rasmussen, T.B.; Friedrich, K.; Uthe, F.; et al. Ajoene, a sulfur-rich molecule from garlic, inhibits genes controlled by quorum sensing. Antimicrob. Agents Chemother. 2012, 56, 2314-2325. [CrossRef] [PubMed]

195. Walker, T.S.; Bais, H.P.; Deziel, E.; Schweizer, H.P.; Rahme, L.G.; Fall, R.; Vivanco, J.M. Pseudomonas aeruginosa-plant root interactions. Pathogenicity, biofilm formation, and root exudation. Plant. Physiol. 2004, 134, 320-331. [CrossRef] [PubMed]

196. Zhou, L.; Zheng, H.; Tang, Y.; Yu, W.; Gong, Q. Eugenol inhibits quorum sensing at sub-inhibitory concentrations. Biotechnol. Lett. 2013, 35, 631-637. [CrossRef]

197. Girennavar, B.; Cepeda, M.L.; Soni, K.A.; Vikram, A.; Jesudhasan, P.; Jayaprakasha, G.K.; Pillai, S.D.; Patil, B.S. Grapefruit juice and its furocoumarins inhibits autoinducer signaling and biofilm formation in bacteria. Int. J. Food Microbiol. 2008, 125, 204-208. [CrossRef] [PubMed]

198. Ding, X.; Yin, B.; Qian, L.; Zeng, Z.; Yang, Z.; Li, H.; Lu, Y.; Zhou, S. Screening for novel quorum-sensing inhibitors to interfere with the formation of Pseudomonas aeruginosa biofilm. J. Med. Microbiol. 2011, 60, 1827-1834. [CrossRef]

199. Zeng, Z.; Qian, L.; Cao, L.; Tan, H.; Huang, Y.; Xue, X.; Shen, Y.; Zhou, S. Virtual screening for novel quorum sensing inhibitors to eradicate biofilm formation of Pseudomonas aeruginosa. Appl. Microbiol. Biotechnol. 2008, 79, 119-126. [CrossRef]

200. Vadhana, P.; Singh, B.R.; Bharadwaj, M.; Singh, S.V. Emergence of herbal antimicrobial drug resistance in clinical bacterial isolates. Pharm. Anal. Acta 2015, 6, 1-7. [CrossRef] 
201. Warnke, P.H.; Becker, S.T.; Podschun, R.; Sivananthan, S.; Springer, I.N.; Russo, P.A.; Wiltfang, J.; Fickenscher, H.; Sherry, E. The battle against multi-resistant strains: Renaissance of antimicrobial essential oils as a promising force to fight hospital-acquired infections. J. Cranio Maxillofac Surg. 2009, 37, 392-397. [CrossRef]

202. Pisoschi, A.M.; Pop, A.; Georgescu, C.; Turcus, V.; Olah, N.K.; Mathe, E. An overview of natural antimicrobials role in food. Eur. J. Med. Chem. 2018, 143, 922-935. [CrossRef]

203. Singh, B.R.; Singh, V.; Ebibeni, N.; Singh, R.K. Antimicrobial and herbal drug resistance in enteric bacteria isolated from faecal droppings of common house lizard/gecko (Hemidactylus frenatus). Int. J. Microbiol. 2013, 2013, 340848. [CrossRef]

204. Gupta, P.D.; Birdi, T.J. Development of botanicals to combat antibiotic resistance. J. Ayurveda Integr. Med. 2017, 8, 266-275. [CrossRef] [PubMed]

205. San Millan, A.; MacLean, R.C. Fitness costs of plasmids: A limit to plasmid transmission. Microbiol. Spectr. 2017, 5, 65-79.

206. Durão, P.; Balbontín, R.; Gordo, I. Evolutionary mechanisms shaping the maintenance of antibiotic resistance. Trends Microbiol. 2018, 26, 677-691. [CrossRef] [PubMed]

207. Melnyk, A.H.; Wong, A.; Kassen, R. The fitness costs of antibiotic resistance mutations. Evol. Appl. 2015, 8, 273-283. [CrossRef]

208. Sang, Y.; Blecha, F. Antimicrobial peptides and bacteriocins: Alternatives to traditional antibiotics. Anim. Health Res. Rev. 2008, 9, 227-235. [CrossRef]

209. Hintz, T.; Matthews, K.K.; Di, R. The use of plant antimicrobial compounds for food preservation. BioMed Res. Int. 2015, 2015, 246264. [CrossRef]

210. McGuiness, W.A.; Malachowa, N.; DeLeo, F.R. Vancomycin resistance in Staphylococcus aureus. Yale J. Biol. Med. 2017, 90, 269-281.

211. Nannini, E.; Murray, B.E.; Arias, C.A. Resistance or decreased susceptibility to glycopeptides, daptomycin, and linezolid in methicillin-resistant Staphylococcus aureus. Curr. Opin. Pharm. 2010, 10, 516-521. [CrossRef]

212. Cui, L.; Iwamoto, A.; Lian, J.Q.; Neoh, H.M.; Maruyama, T.; Horikawa, Y.; Hiramatsu, K. Novel mechanism of antibiotic resistance originating in vancomycin-intermediate Staphylococcus aureus. Antimicrob. Agents Chemother. 2006, 50, 428-438. [CrossRef]

213. Baltz, R.H. Genetic manipulation of secondary metabolite biosynthesis for improved production in Streptomyces and other actinomycetes. J. Ind. Microbiol. Biotechnol. 2016, 43, 343-370. [CrossRef]

214. Johnston, C.W.; Connaty, A.D.; Skinnider, M.A.; Li, Y.; Grunwald, A.; Wyatt, M.A.; Kerr, R.G.; Magarvey, N.A. Informatic search strategies to discover analogues and variants of natural product archetypes. J. Ind. Microbiol. Biotechnol. 2016, 43, 293-298. [CrossRef] [PubMed]

215. Medema, M.H.; Fischbach, M.A. Computational approaches to natural product discovery. Nat. Chem. Biol. 2015, 11, 639-648. [CrossRef]

216. Katz, M.; Hover, B.M.; Brady, S.F. Culture-independent discovery of natural products from soil metagenomes. J. Ind. Microbiol. Biotechnol. 2016, 43, 129-141. [CrossRef] [PubMed]

217. Zakeri, B.; Lu, T.K. Synthetic biology of antimicrobial discovery. ACS Synth. Biol. 2013, 2, 358-372. [CrossRef] [PubMed]

218. Morris, G.M.; Lim-Wilby, M. Molecular Modeling of Proteins; Humana Press: Totowa, NJ, USA, 2008; Volume 443.

219. Saikia, S.; Bordoloi, M. Molecular docking: Challenges, advances and its use in drug discovery perspective. Curr. Drug Targets 2019, 20, 501-521. [CrossRef] [PubMed]

220. Gertsch, J. Botanical drugs, synergy, and network pharmacology: Forth and back to intelligent mixtures. Planta Med. 2011, 77, 1086-1098. [CrossRef] [PubMed]

221. Moore, B.S.; Carter, G.T.; Bronstrup, M. Editorial: Are natural products the solution to antimicrobial resistance? Nat. Prod. Rep. 2017, 34, 685-686. [CrossRef] [PubMed]

(C) 2020 by the authors. Licensee MDPI, Basel, Switzerland. This article is an open access article distributed under the terms and conditions of the Creative Commons Attribution (CC BY) license (http://creativecommons.org/licenses/by/4.0/). 